\title{
10. SEDIMENTATION OF COARSER GRAINED INTERBEDS IN THE ARABIAN SEA AND SEDIMENTATION PROCESSES OF THE INDUS CONE
}

\author{
Dan Jipa, Institutul Geologic, Bucharest, Romania \\ and \\ Robert B. Kidd, ${ }^{1}$ University of Southampton, United Kingdom
}

\begin{abstract}
This sedimentologic study is based on material sampled during Leg 23 in the Arabian Sea. It has shown that, in the sedimentary history of the Indus Cone, the deposition of terrigenous fine silt and clay on a major scale has been an almost permanent feature of the environment.

The classic concept of the development of submarine fans by spasmodic deposition from turbidity currents receives critical appraisal. The turbidity current mechanism alone is insufficient to explain the sedimentary sequences encountered. A variety of sedimentation mechanisms have combined in building up the great thickness of Indus Cone sediment.

It appears that the major contribution of terrigenous material has been by the deposition of fine silt and clay from turbid flows originating in shelf areas. The possibilities of these flows being of the suspended type, entering the water column along water density interfaces, or of bottom-following type, are discussed. Other fine sediments from winds and surface currents combine with the flows to supply a continuous silty clayey suspension to the surface of the submarine fan.

Graded interbeds of coarse silt and fine sand within the sedimentary sequence are probably the result of intermittent events involving turbidity current activity. Most of the sands have originated from the mouth of the Indus River, but others can be shown to have come from other sources, for example, farther south on the Indian Shelf and the Laccadive-Maldive Ridge.

Evidence of more permanent bottom current activity is presented. This seems to most readily fit an overall Indus Cone development by a sedimentation process involving semipermanent bottom following turbid flows of fine sediment together with spasmodic turbidity current deposition of coarse silt and fine sand.

Minor intervals of pelagic sediments mixed with land-derived fine clastic material indicate long periods when the turbid flow mechanism was less active. This could have been due to restricted Indus River supply or to climatic changes.
\end{abstract}

\section{INTRODUCTION}

For the purposes of this study, the Indus Cone is defined as the fan-shaped submarine geomorphic feature of the Arabian Sea, having its apex around Karachi, and bounded by the Owen/Murray Ridge system to the north and northwest, the Indian continental shelf and LaccadiveMaldive Ridge to the east, and the Arabian Abyssal Plain to the south (at about $15^{\circ} \mathrm{N}$ ).

\footnotetext{
${ }^{1}$ Present address: National Institute of Oceanography, Wormley, Godalming, Surrey, United Kingdom.
}

The study was initiated, during drilling operations at Sites 221 and 222, as an inquiry into the sedimentation of sand and silt beds intercalated in the dominantly fine-grained sequences encountered. It was found necessary to critically examine the finer background lithologies also. The investigation was further extended to include samples from similar sequences, presumably outside the influence of the Indus Cone sedimentary environment (at Sites 223 and 224), for comparison.

The information presented in this paper now permits discussion of mechanisms involved in the development of the submarine fan. 


\section{SHIPBOARD CORE EXAMINATION AND SAMPLING}

The authors conducted a detailed examination of every distinct sand or silt bed in the cores from Sites 221 to 224 . Sketches were made, closeup photographs taken, and careful note made of all visible sedimentary structures. Sometimes difficulties arose in defining the upper and lower boundaries of some beds, particularly those which were graded. On transitional boundaries, limits were set where visible coarser texture, sedimentary structures, or inherent bed color died out.

Ten beds were chosen which showed minimal coring disturbance, and a set of samples was collected from each. The authors collected samples for their own compositional (R.K.) and textural (D.J.) studies. From the 10 beds, 21 samplęs were taken primarily for study of sand composition and 33 for detailed grain-size analysis. In addition, 13 grain-size samples were taken from the silty clay background lithologies for textural comparison with the intercalated beds, also, all relevant shipboard smear slides were reexamined to provide compositional comparison.

Robert Fleisher and Joseph Boudreaux kindly analyzed, mostly aboard the Glomar Challenger, about 20 samples for foraminiferal and nannofossil content.

Samples from the chosen beds were collected for DSDP shore laboratory analyses of carbon-carbonate content, $\mathrm{X}$-ray mineralogy, and grain size. Data from these analyses has also, therefore, been incorporated in this study.

\section{POST-CRUISE LABORATORY PROCEDURES}

\section{Compositional Analysis}

A smear slide examination was made of each of the selected samples. This provided information on overall composition, particularly on the silt-size fraction. The samples were then washed, dispersed, and wet sieved at 62 microns. The resulting sand fraction was dried. The sieving procedure and smear slide examination also provided approximate textural information.

The dry sands were examined with reflected light under a binocular biological microscope and then split using a Skolnick-type microsplitter; the split being mounted in Caedax for counting. The remaining sand was separated in bromoform (S.G. 2.89), and both light and heavy fractions were mounted in Caedax for microscopic examination. The heavy fraction was point-counted where it represented the base of the sampled sequence, or if a higher percentage was recovered farther up the bed, this was counted in its place.

The preliminary microscopic examination enabled the selection of categories to be used in the counting of the sand and heavy mineral fractions. The counting was carried out using a Leitz polarizing microscope in conjunction with a Swift counter and moving stage.

Tables 1 to 4 display the results for each site of the sand fraction counting, together with X-ray mineralogy and carbon-carbonate data of samples taken in the relevant beds. These sand counts are based on the grid type movement of the stage, and in all cases, at least 300 grains were counted. Results are given as percentages of the number of grains counted. Results from thin sections, counted in a similar manner, incorporate a "matrix/ cement" category.

In the heavy mineral separations, diagnostic minerals were completely masked by micas together with crystalline carbonate and opaque grains. Because of the hydraulic behavior of micas which makes them nondiagnostic, they have not been counted. For counting, categories were erected of minerals considered to be diagnostic for studies of provenance. The counting recorded EVERY GRAIN which fell in these categories, resulting in counted totals varying from 327 to 11 grains. Since calculated percentages would not be statistically comparable, Table 5 records only the raw count data.

The smear slides are important for an understanding of the overall background lithology in which the coarser interbeds occur. As regards categorizing and naming of lithologic types, an approach similar to that used for shipboard studies has been used during their reexamination. In particular, the carbonate particles are considered as being of clastic origin when coarse grained. They occur in sediments which are interpreted as being reworked and have either been transported by ocean currents or winds. Fine micarb particles are probably derived from nannofossils and have a different origin. Other materials which, in the presence of other evidence of reworking, are included with the clastic component are: fecal pellets, plant debris, nonindigenous fossil remains, etc. Samples from presentday beach sands from the Muscat coastline were examined for comparative mineralogy with the sand fractions of Sites 223 and 224.

\section{Grain Size Analysis}

Detailed grain-size analyses were carried out by sieving the sand fraction and pipetting the silt and clay-size material. Sieving was done with an electric Thyr 1 (VEB Labortechnik) sieve shaker and $19 \mathrm{~cm}$ diameter sieves. The following set of sieves was used (dimensions in microns): 62-80-90-100-125-160-200-250-315-400-500-630-800-1000. The sample was initially washed on the 62 microns sieve. The fraction coarser grained than 62 microns was dried and sieved for at least 30 minutes. In some cases no sieving was accomplished, the total amount of sand being very small. The part of the sample which passed through the 62 microns sieve was analyzed following the standard pipette procedure (Krumbein and Pettijohn, 1938). Samples were physically dispersed in distilled water without intervention of a dispersing agent. Pipette samples were collected to indicate every $1 / 2$ phi in the interval from 4 phi to 10 phi (62 to 1 microns). Combined results of both sieving and pipetting were plotted on phi-probability paper. Graphic grain-size parameters (median, mean, standard deviation, skewness and kurtosis) have been obtained using Folk and Ward (1957) formulae.

\section{PRESENTATION OF DATA}

\section{The Coarse-Grained Interbeds}

\section{Gross Bedding Relationships}

In the Arabian Sea sediment sequences, the coarser grained (mostly silty) beds occur as intercalations less than $1 \mathrm{~cm}$ thick in long successions of considerably finer texture. 
TABLE 1

Detailed Sample Sequences, Site 221

\begin{tabular}{|c|c|c|c|c|c|c|c|c|c|c|c|c|}
\hline \multicolumn{13}{|c|}{ Percentage Content of the Sand Fraction } \\
\hline $\begin{array}{l}\text { Core- } \\
\text { Section }\end{array}$ & $\begin{array}{l}\text { Interval } \\
(\mathrm{cm})\end{array}$ & Forams & Spicules & $\begin{array}{c}\text { Plant } \\
\text { Remains }\end{array}$ & Rads. & $\begin{array}{c}\text { Other } \\
\text { Biogenous }\end{array}$ & $\begin{array}{c}\text { Rock } \\
\text { Fragments }\end{array}$ & $\begin{array}{c}\text { Other } \\
\text { Minerals }\end{array}$ & $\mathrm{Qz}$ & Fels & Mica & $\begin{array}{c}\text { Heavy } \\
\text { Minerals }\end{array}$ \\
\hline $5-4$ & $\begin{array}{l}40-42 \\
46-48\end{array}$ & $\begin{array}{l}23.2 \\
19.0\end{array}$ & $\begin{array}{l}0.3 \\
1.6\end{array}$ & $\begin{array}{l}2.2 \\
0.3\end{array}$ & $\begin{array}{l}3.7 \\
2.2\end{array}$ & $\begin{array}{l}48.3 \\
52.7\end{array}$ & $\begin{array}{l}0.6 \\
0.6\end{array}$ & $\begin{array}{c}0.3 \\
-\end{array}$ & $\begin{array}{l}3.7 \\
7.0\end{array}$ & $\begin{array}{l}1.3 \\
0.9\end{array}$ & $\begin{array}{l}13.6 \\
14.0\end{array}$ & $\begin{array}{l}2.8 \\
1.6\end{array}$ \\
\hline $8-2$ & $\begin{array}{l}57-80 \\
83-85\end{array}$ & $\begin{array}{l}0.4 \\
1.3\end{array}$ & $\begin{array}{l}0.4 \\
-\end{array}$ & $\begin{array}{l}8.8 \\
0.3\end{array}$ & $\begin{array}{c}0.4 \\
-\end{array}$ & $\begin{array}{l}2.6 \\
4.3\end{array}$ & $\begin{array}{l}0.8 \\
2.3\end{array}$ & - & $\begin{array}{r}1.6 \\
11.0\end{array}$ & $\begin{array}{l}1.2 \\
6.0\end{array}$ & $\begin{array}{l}84.3 \\
71.3\end{array}$ & $-\overline{3.3}$ \\
\hline $10-6$ & $1-3$ & 17.6 & 3.7 & - & 1.6 & 68.4 & - & - & 2.7 & - & 5.9 & - \\
\hline $12-2$ & $\begin{array}{l}53-55 \\
61-63\end{array}$ & $\begin{array}{l}0.7 \\
0.9\end{array}$ & $\begin{array}{l}0.3 \\
0.9\end{array}$ & $\begin{array}{r}58.7 \\
7.3\end{array}$ & $\begin{array}{c}0.7 \\
-\end{array}$ & $\begin{array}{r}11.7 \\
1.8\end{array}$ & $\overline{0.6}$ & - & $\begin{array}{l}1.3 \\
8.9\end{array}$ & $\overline{4.1}$ & $\begin{array}{l}35.2 \\
70.2\end{array}$ & $\begin{array}{l}1.3 \\
5.4\end{array}$ \\
\hline
\end{tabular}

Bulk X-ray Mineralogy (Percentages of total sediment)

\begin{tabular}{|c|c|c|c|c|c|c|c|c|c|c|c|c|c|c|}
\hline $\begin{array}{l}\text { Core- } \\
\text { Section }\end{array}$ & $\begin{array}{l}\text { Interval } \\
(\mathrm{cm})\end{array}$ & Calc. & Dolo. & Arag. & $\mathrm{Qz}$ & K-Fels & $\begin{array}{l}\text { Plag } \\
\text { Fels }\end{array}$ & Mica & Chlo. & Kaol. & Mont. & Clin. & Amph. & Pyr. \\
\hline $5-4$ & $33-35$ & 10.3 & 0.8 & 63.3 & 5.5 & - & 3.1 & 13.9 & 1.7 & - & - & 0.6 & 0.7 & - \\
\hline $8-2$ & $\begin{array}{c}1-2 \\
29-31 \\
55-57\end{array}$ & $\begin{array}{r}9.4 \\
10.6 \\
7.6\end{array}$ & $\begin{array}{l}1.8 \\
1.7 \\
1.2\end{array}$ & $\begin{array}{l}- \\
-\end{array}$ & $\begin{array}{l}19.5 \\
20.4 \\
21.8\end{array}$ & $\begin{array}{l}1.7 \\
1.9 \\
5.2\end{array}$ & $\begin{array}{r}5.6 \\
5.7 \\
10.2\end{array}$ & $\begin{array}{l}53.7 \\
51.0 \\
47.5\end{array}$ & $\begin{array}{l}8.4 \\
8.6 \\
6.3\end{array}$ & $\begin{array}{l}- \\
-\end{array}$ & $\begin{array}{l}- \\
- \\
-\end{array}$ & $\begin{array}{l}- \\
-\end{array}$ & $\begin{array}{l}- \\
-\end{array}$ & $\begin{array}{l}- \\
-\end{array}$ \\
\hline $10-5$ & $\begin{array}{c}87-89 \\
136-138\end{array}$ & $\begin{array}{r}15.9 \\
9.5\end{array}$ & $\begin{array}{l}1.3 \\
-\end{array}$ & $\begin{array}{l}68.4 \\
77.6\end{array}$ & $\begin{array}{l}4.1 \\
4.1\end{array}$ & $\begin{array}{l}- \\
-\end{array}$ & $\begin{array}{l}1.2 \\
1.0\end{array}$ & $\begin{array}{l}7.9 \\
6.6\end{array}$ & $\begin{array}{l}1.2 \\
1.0\end{array}$ & $\begin{array}{l}- \\
-\end{array}$ & $\begin{array}{l}- \\
-\end{array}$ & $\begin{array}{l}- \\
-\end{array}$ & - & - \\
\hline $12-2$ & $\begin{array}{c}1-3 \\
63-65\end{array}$ & $\begin{array}{l}12.1 \\
12.1\end{array}$ & $\begin{array}{l}1.6 \\
1.6\end{array}$ & $\begin{array}{l}- \\
-\end{array}$ & $\begin{array}{l}21.3 \\
21.5\end{array}$ & $\overline{1.2}$ & $\begin{array}{l}4.6 \\
3.8\end{array}$ & $\begin{array}{l}51.4 \\
50.6\end{array}$ & $\begin{array}{l}9.0 \\
9.2\end{array}$ & - & - & $\begin{array}{l}- \\
-\end{array}$ & - & - \\
\hline
\end{tabular}

Carbon-Carbonate Content (Percentages of Total Sediment)

\begin{tabular}{crccc}
\hline $\begin{array}{c}\text { Core- } \\
\text { Section }\end{array}$ & $\begin{array}{c}\text { Interval } \\
(\mathrm{cm})\end{array}$ & Carbon Total & Carbon Organic & $\mathrm{Ca} \mathrm{CO}_{3}$ \\
\hline \multirow{2}{*}{$5-3$} & 133 & 7.6 & 0.7 & 58.0 \\
$5-4$ & 31 & 8.1 & 0.4 & 64.0 \\
& 46 & 7.6 & 0.3 & 60.0 \\
$8-2$ & 47 & 2.0 & 0.4 & 13.0 \\
& 67 & 1.8 & 0.3 & 13.0 \\
& 83 & 1.6 & 0.2 & 11.0 \\
$10-5$ & 115 & 9.2 & 0.5 & 73.0 \\
& 149 & 9.3 & 0.3 & 75.0 \\
$10-6$ & 4 & 9.7 & 0.2 & 79.0 \\
$12-2$ & 20 & 2.0 & 0.4 & 13.0 \\
& 45 & 2.2 & 0.4 & 15.0 \\
& 60 & 0.3 & 1.0 & 11.0 \\
\hline
\end{tabular}

The greatest number of these silty intercalations was found at Site 222 (Figure 1). There, almost 150 silty beds were observed. The figure shows that visually 1 - to 8 -cm-thick beds were dominant, with frequency peaks in the $4-$ to $8-\mathrm{cm}$ and $1-$ to $2-\mathrm{cm}$ classes (see Figure 2). The maximum visible thickness of intercalation observed was 1 meter.

Most of the silty interbeds at Site 222 were confined to five cores. Two intervals with an abundance of silty interbeds are recognized, one in the lower part of the Early Pliocene (Cores 8 and 9) and the second, less sharply defined, in the Late Miocene (Cores 25, 28, and 34).

Many cores collected at Site 222 contained silty intercalations less than $1 \mathrm{~cm}$ thick (herein defined as silt laminae), and some contained homogeneous clayey sediments with no coarse interbeds at all.

At Site 221, the silty intercalations occurred within units I and II. Only about twenty interbeds were noted.
They may actually have been more numerous as core recovery was low and a high degree of drilling disturbance was present in some of the cores. The thickest bed observed at Site 221 was a $71-\mathrm{cm}$-thick intercalation (see Figure 3). Most beds were between 2 and $16 \mathrm{~cm}$ thick (Figure 4). The frequency of silty beds at this site is highest in Cores 8,9 , and 10, spanning the Early Pleistocene interval.

Unlike Sites 222 and 221, only a minor portion of the cored sequences at Sites 223 and 224 contain silty interbeds.

\section{Sediment Structures}

\section{Graded Beds}

Many intercalations showed grading of their clastic material. The following types were observed:

1) Normal grading-a coarser grained basal deposit becomes finer towards the upper part of the bed. Usually, 
TABLE 2

Detailed Sample Sequences, Site 222

\begin{tabular}{|c|c|c|c|c|c|c|c|c|c|c|c|c|}
\hline \multirow[b]{2}{*}{$\begin{array}{l}\text { Core- } \\
\text { Section }\end{array}$} & \multicolumn{11}{|c|}{ Percentage Content of the Sand Fraction } & \multirow[b]{2}{*}{$\begin{array}{c}\text { Heavy } \\
\text { Minerals }\end{array}$} \\
\hline & $\begin{array}{c}\text { Interval } \\
(\mathrm{cm})\end{array}$ & Forams & Spicules & $\begin{array}{c}\text { Plant } \\
\text { Remains }\end{array}$ & Rads. & $\begin{array}{c}\text { Other } \\
\text { Biogenous }\end{array}$ & $\begin{array}{c}\text { Rock } \\
\text { Fragments }\end{array}$ & $\begin{array}{l}\text { Other } \\
\text { Minerals }\end{array}$ & Qz & Fels & Mica & \\
\hline $6-4$ & $\begin{array}{l}124-126 \\
133-135\end{array}$ & $\overline{2.5}$ & $\begin{array}{c}0.6 \\
-\end{array}$ & $\begin{array}{c}2.3 \\
-\end{array}$ & $\overline{-}$ & $\begin{array}{l}2.6 \\
5.6\end{array}$ & $\begin{array}{r}0.9 \\
13.4\end{array}$ & - & $\begin{array}{r}2.3 \\
28.1\end{array}$ & $\begin{array}{r}0.9 \\
10.9\end{array}$ & $\begin{array}{l}82.9 \\
29.4\end{array}$ & $\begin{array}{r}7.5 \\
10.0\end{array}$ \\
\hline $\begin{array}{l}9-3 \\
9-4\end{array}$ & $\begin{array}{c}137.5-139.5 \\
25.5-27.5 \\
89-91\end{array}$ & $\begin{array}{l}1.0 \\
1.0 \\
0.8\end{array}$ & $\begin{array}{l}0.3 \\
- \\
-\end{array}$ & $\begin{array}{l}2.1 \\
1.0 \\
0.3\end{array}$ & $\begin{array}{l}- \\
0.3 \\
-\end{array}$ & $\begin{array}{l}2.9 \\
3.5 \\
6.2\end{array}$ & $\begin{array}{r}2.1 \\
3.2 \\
13.0\end{array}$ & $\begin{array}{l}- \\
-\end{array}$ & $\begin{array}{r}4.2 \\
9.3 \\
44.4\end{array}$ & $\begin{array}{l}3.9 \\
6.1 \\
7.1\end{array}$ & $\begin{array}{r}70.7 \\
67.9 \\
6.8\end{array}$ & $\begin{array}{r}12.8 \\
4.5 \\
21.5\end{array}$ \\
\hline \multirow[t]{2}{*}{$28-5$} & $63-65$ & 0.3 & - & 0.3 & - & 1.4 & 7.9 & $\begin{array}{l}44.5 \\
\text { micrite } \\
\text { matrix }\end{array}$ & 30.00 & 5.2 & 2.5 & 7.9 \\
\hline & $93-94.5$ & 3.7 & - & 0.3 & - & 7.0 & 1.9 & - & 33.0 & 9.0 & 11.7 & 16.0 \\
\hline
\end{tabular}

Bulk X-ray Mineralogy (Percentages of total sediment)

\begin{tabular}{|c|c|c|c|c|c|c|c|c|c|c|c|c|c|c|}
\hline $\begin{array}{l}\text { Core- } \\
\text { Section }\end{array}$ & $\begin{array}{c}\text { Interval } \\
(\mathrm{cm})\end{array}$ & Calc. & Dolo. & Arag. & $\mathrm{Qz}$ & K-Fels & $\begin{array}{l}\text { Plag. } \\
\text { Fels }\end{array}$ & Mica & Chlo. & Kaol. & Mont. & Clin. & Amph. & Pyr. \\
\hline $6-4$ & $112.5-114.5$ & 12.0 & 2.0 & - & 26.6 & - & 7.5 & 44.0 & 7.9 & - & - & - & - & - \\
\hline $9-3$ & $84-86$ & 11.6 & 1.8 & - & 23.9 & 2.1 & 7.9 & 43.9 & 8.8 & - & - & - & - & - \\
\hline $9-4$ & $11-13$ & 7.2 & 1.2 & - & 28.3 & 2.4 & 13.0 & 40.3 & 5.9 & - & - & - & - & - \\
\hline $28-5$ & $72-73$ & 16.3 & 2.6 & - & 26.5 & 3.1 & 7.8 & 31.0 & 7.2 & 3.5 & 2.0 & - & - & - \\
\hline
\end{tabular}

Carbon-Carbonate Content (Percentages of total sediment)

\begin{tabular}{ccccc}
\hline $\begin{array}{c}\text { Core- } \\
\text { Section }\end{array}$ & $\begin{array}{c}\text { Interval } \\
(\mathrm{cm})\end{array}$ & Carbon Total & Carbon Organic & $\mathrm{CaCO}_{3}$ \\
\hline \multirow{2}{*}{$6-4$} & 118 & 2.0 & 0.3 & 14.0 \\
& 222 & 2.0 & 0.3 & 15.0 \\
$9-3$ & 81 & 2.1 & 0.3 & 15.0 \\
& 114 & 2.1 & 0.2 & 16.0 \\
$9-4$ & 29 & 1.7 & 0.1 & 13.0 \\
$28-5$ & 76 & 1.9 & 0.3 & 13.0 \\
& 86 & 2.0 & 0.3 & 14.0 \\
& 92 & 2.1 & 0.3 & 15.0 \\
\hline
\end{tabular}

the lower boundary of the bed is sharp and the upper one displays a gradual passage from silt to silty clay.

2) Normal grading as above, with sharp contacts at both bottom and top.

3) Inverted grading - a gradual passage from silty clays at the base of the bed, becoming coarsest at the middle, and followed by a gradual transition again into clayey silts.

Type 1 normal grading was most common, representing 64 percent of the beds at Site 222 and 53 percent at Site 221. (Figures 2 and 4). Beds with normal grading and sharp upper contacts constitute a further 8 percent of the total intercalations at Site 222 and 6 percent at Site 221. Three inverted graded beds and one symmetrically graded bed were noted at Site 222, representing 2 percent and 1 percent, respectively, of the total number of interbeds there.

\section{Nongraded Beds}

Intercalations of coarser grained sediments apparently devoid of grading were frequently observed. Contacts with the fine background lithologies were invariably sharp at both the base and top of the beds. Nongraded beds represent 18 percent of the total number of observed intercalations at Site 222 and 24 percent at Site 221. Their thicknesses were usually between 2 and $16 \mathrm{~cm}$ (Figures 2 and 4).

\section{Laminations}

This sedimentary feature is quite common for many intercalations at Sites 222 and 221 . Both cross and parallel lamination were observed.

Cross lamination sometimes occurs within graded beds where two genetic types can be distinguished: (a) truncated fore-set lamination (Figures 5B, E, F, G, H, I) and (b) climbing ripple lamination (Figures $5 \mathrm{~A}$ and 5D). The fore-set type usually appears at the top of a bed (Figure $5 \mathrm{G})$, in which case the upper boundary of the graded bed is sharp. Occasionally, it is observed at the bottom of a bed in the material filling an erosional sole marking (Figure 5I). The grading is not interrupted when the climbing type appears. The climbing ripple laminae seem to occupy the upper half of the bed. When cross lamination is not related to graded bedding, several superimposed units may appear (Figure $5 \mathrm{H}$ ) consisting of truncated oblique laminae. 
TABLE 3

Detailed Sample Sequences, Site 223

\begin{tabular}{|c|c|c|c|c|c|c|c|c|c|c|c|c|c|c|c|}
\hline \multicolumn{16}{|c|}{ Percentage Content of the Sand Fraction } \\
\hline $\begin{array}{c}\text { Core- } \\
\text { Section }\end{array}$ & $\begin{array}{l}\text { Interval } \\
(\mathrm{cm})\end{array}$ & Forams & Spicules & $\begin{array}{l}\text { Plan } \\
\text { Rem }\end{array}$ & & Rads. & $\begin{array}{c}\text { Other } \\
\text { Biogenous }\end{array}$ & $\begin{array}{r}\mathrm{Rc} \\
\text { Fragr }\end{array}$ & $\begin{array}{l}\text { ck } \\
\text { lents }\end{array}$ & $\begin{array}{l}\text { Other } \\
\text { Minerals }\end{array}$ & $\mathrm{Qz}$ & Fels & Mica & $\begin{array}{r}\mathrm{He} \\
\mathrm{Min}\end{array}$ & $\begin{array}{l}\text { avy } \\
\text { erals }\end{array}$ \\
\hline $2-2$ & $\begin{array}{c}89-91 \\
139-141\end{array}$ & $\begin{array}{l}16.1 \\
18.5\end{array}$ & $\begin{array}{l}2.3 \\
2.9\end{array}$ & $\begin{array}{c}0.3 \\
-\end{array}$ & & $\begin{array}{l}1.6 \\
1.0\end{array}$ & $\begin{array}{l}21.5 \\
25.1\end{array}$ & $\begin{array}{r}13 \\
8\end{array}$ & & - & $\begin{array}{l}23.0 \\
24.8\end{array}$ & $\begin{array}{l}3.0 \\
1.9\end{array}$ & $\begin{array}{l}2.0 \\
1.0\end{array}$ & & $\begin{array}{l}5.1 \\
6.9\end{array}$ \\
\hline $2-3$ & $38-39$ & 16.8 & 1.2 & 0.3 & & 2.1 & 39.5 & 6 & & - & 20.1 & 1.8 & 0.6 & & 1.4 \\
\hline $19-2$ & $\begin{array}{l}125-127 \\
140-142\end{array}$ & $\begin{array}{l}15.1 \\
12.7\end{array}$ & $\begin{array}{l}0.9 \\
3.5\end{array}$ & - & & $\begin{array}{l}0.9 \\
0.4\end{array}$ & $\begin{array}{l}31.4 \\
35.1\end{array}$ & $\begin{array}{l}11 \\
11\end{array}$ & & - & $\begin{array}{l}20.4 \\
19.2\end{array}$ & $\begin{array}{l}3.5 \\
0.4\end{array}$ & $\begin{array}{l}1.6 \\
2.2\end{array}$ & & $\begin{array}{l}5.0 \\
4.5\end{array}$ \\
\hline \multicolumn{16}{|c|}{ Bulk X-ray Mineralogy (Percentages of total sediment) } \\
\hline $\begin{array}{c}\text { Core- } \\
\text { Section }\end{array}$ & $\begin{array}{l}\text { Interval } \\
(\mathrm{cm})\end{array}$ & Calc. & Dolo. & Arag. & $\mathrm{Qz}$ & K-Fel & $\begin{array}{ll} & \text { Plag } \\
\text { ls } & \text { Fels }\end{array}$ & Mica & Chlo. & Kaol. & Mont. & Paly. & $\mathrm{Ar}$ & $\mathrm{mph}$. & Pyr. \\
\hline $19-2$ & $\begin{array}{l}19-21 \\
58-60\end{array}$ & $\begin{array}{l}15.2 \\
18.3\end{array}$ & $\begin{array}{l}2.3 \\
2.4\end{array}$ & - & $\begin{array}{l}28.8 \\
31.7\end{array}$ & - & $\begin{array}{r}6.9 \\
11.7\end{array}$ & $\begin{array}{l}25.8 \\
22.3\end{array}$ & $\begin{array}{l}7.9 \\
7.5\end{array}$ & - & - & $\begin{array}{r}11.6 \\
6.1\end{array}$ & & - & $\begin{array}{l}1.6 \\
-\end{array}$ \\
\hline
\end{tabular}

Carbon-Carbonate Content (Percentages of total sediment)

\begin{tabular}{ccccc}
\hline $\begin{array}{c}\text { Core- } \\
\text { Section }\end{array}$ & $\begin{array}{c}\text { Interval } \\
(\mathrm{cm})\end{array}$ & Carbon Total & Carbon Organic & $\mathrm{CaCO}_{3}$ \\
\hline $2-2$ & 100 & 6.2 & 0.2 & 50.0 \\
$2-3$ & 13 & 7.1 & 0.5 & 55.0 \\
$19-2$ & 40 & 2.0 & 0.3 & 14.0 \\
& 100 & 2.2 & 0.2 & 17.0 \\
& 135 & 3.7 & 0.3 & 28.0 \\
\hline
\end{tabular}

TABLE 4

Detailed Sample Sequence, Site 224

\begin{tabular}{cccccccccccccc}
\hline \multicolumn{10}{c}{ Percentage Content of the Sand Fraction } \\
\hline $\begin{array}{c}\text { Core- } \\
\text { Section }\end{array}$ & $\begin{array}{c}\text { Interval } \\
(\mathrm{cm})\end{array}$ & Forams & Spicules & $\begin{array}{c}\text { Plant } \\
\text { Remains }\end{array}$ & Rads. & $\begin{array}{c}\text { Other } \\
\text { Biogenous }\end{array}$ & $\begin{array}{c}\text { Rock } \\
\text { Fragments }\end{array}$ & $\begin{array}{c}\text { Other } \\
\text { Minerals }\end{array}$ & Qz & Fels & Mica & $\begin{array}{c}\text { Heavy } \\
\text { Minerals }\end{array}$ \\
\hline \multirow{2}{*}{$8-5$} & $28-29$ & 1.6 & - & - & - & 16.1 & 22.9 & - & 32.5 & 3.6 & 11.2 & 12.0 \\
& $45-47$ & 0.7 & - & 0.7 & - & 4.9 & 9.8 & - & 19.3 & 3.9 & 56.4 & 4.3 \\
\hline
\end{tabular}

Bulk X-ray Mineralogy (Percentages of total sediment)

\begin{tabular}{|c|c|c|c|c|c|c|c|c|c|c|c|c|c|c|}
\hline $\begin{array}{c}\text { Core } \\
\text { Section }\end{array}$ & $\begin{array}{l}\text { Interval } \\
(\mathrm{cm})\end{array}$ & Calc. & Dolo. & Arag. & $\mathrm{Qz}$ & K-Fels. & $\begin{array}{l}\text { Plag. } \\
\text { Fels. }\end{array}$ & Mica & Chlo. & Kaol. & Mont. & Clin. & Amph. & Pyr. \\
\hline \multirow[t]{2}{*}{$8-5$} & $5-4$ & 9.7 & 2.3 & - & 27.1 & 2.2 & 6.0 & 42.1 & 8.7 & - & 2.0 & - & - & - \\
\hline & $32-33$ & 9.8 & 2.1 & - & 27.1 & 3.2 & 6.4 & 40.1 & 6.4 & 2.9 & 2.2 & - & - & - \\
\hline
\end{tabular}

Carbon-Carbonate Content (Percentages of total sediment)

\begin{tabular}{ccccc}
\hline $\begin{array}{c}\text { Core- } \\
\text { Section }\end{array}$ & $\begin{array}{c}\text { Interval } \\
(\mathrm{cm})\end{array}$ & Carbon Total & Carbon Organic & $\mathrm{Ca} \mathrm{CO}_{3}$ \\
\hline \multirow{2}{*}{$8-5$} & 18 & 1.6 & 0.2 & 12.0 \\
& 32 & 1.8 & 0.2 & 13.0 \\
\hline
\end{tabular}

Parallel lamination was of much more frequent occurrence. It was observed within individual interbeds but was more frequently found associated with the finer background lithologies. Some single discontinuous silty laminae of lensoid shape were noted (Figure 5B).

\section{Description of the Individual Beds}

The graded and nongraded interbeds which were selected for study are described in detail in the appendix to this chapter. Here, only characteristics directly relevant to interpretation have been abstracted, and reference is made to figures and tables of grain-size and compositional data.

\section{Graded Beds}

Graded bed I was from the Upper Pleistocene at Site 221 , where it spans $71 \mathrm{~cm}$ within Core 5 . Its size grading is established in Figure 6, and Tables 1 and 5 display its compositional characteristics. Compositionally, the bed is 


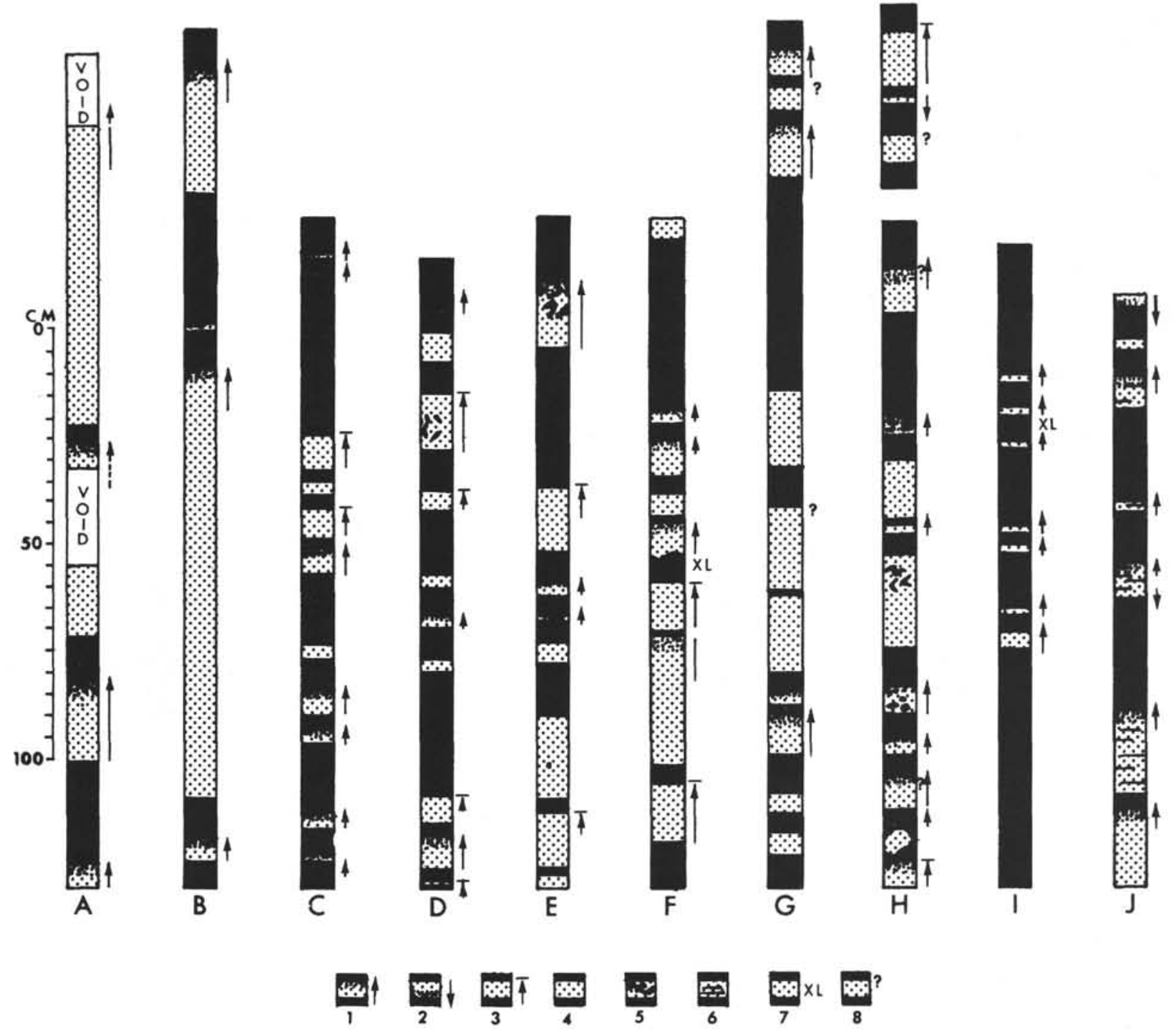

Figure 1. Selected detailed lithologic columns at Site 222. Black= clayey background sediments; Dotted= coarser grained beds; and Arrows indicate direction and span of graded bedding. Features of the coarser grained intercalations:1=normal grading with gradual passage at the top of the bed; $2=$ inverted grading; $3=$ normal grading with sharp boundary at the top of the bed; 4=nongraded beds; 5=clay pebbles (due to drilling disturbances?) in coarser grained sediment; $6=$ coarser grained beds with horizontal lamination; $7=$ coarser grained beds with cross-lamination; and 8=unclear top boundary of the coarser grained bed. Location of the columns (core and section): $\mathrm{A}=9-1$ and $9-2 ; \mathrm{B}=9-4$ and $9-3 ; \mathrm{C}=9-6 ; D=34-3 ; \mathrm{E}=34-4 ; \mathrm{F}=34-5 ; \mathrm{G}=28-2$ and $28-3 ; \mathrm{H}=28-4$ and $28-5 ; \mathrm{I}=34-2$; and $\mathrm{J}=14-3$. Some sections are only partially represented.

distinct from other more highly detrital beds in this core. Aragonitic fecal pellets make up most of the "other biogenous" category and themselves show a size gradation through the bed. Other coarse carbonate material present, such as benthonic foraminifera, ostracods, thick molluscan fragments, and plant debris indicate that the sediment making up this bed has originated in areas shallower than those suggested by its background lithology. The presence of only partially abraded carbonate rhombs suggests transport mainly in suspension.

The 61-cm-graded bed II was sampled from the Lower Pleistocene at the same site $(221)$ in Core 8. Figure 7 displays its textural features and Tables 1 and 5 its composition. Grading is shown, but the sudden increase in silt content in the upper part of the bed has a marked effect on the other parameters plotted. In composition, the bed is more typical of those investigated at Site 221 in its richness of detrital components and very high mica and chlorite content. However, indicators of shallower water derivation similar to those in graded bed I occur, and abraded carbonate rhombs are again present. Both bed types show in their heavy mineral counts the dominance of minerals (garnet, kyanite, actinolite, green hornblende), indicating a metamorphic source and a minor influence of acid igneous derivatives (brown hornblende and microcline).

Graded bed III from Site 221, Core 10 is again of Early Pleistocene age. Figure 8 and Table 1 show its grain-size and compositional characteristics, respectively. The limited sand 


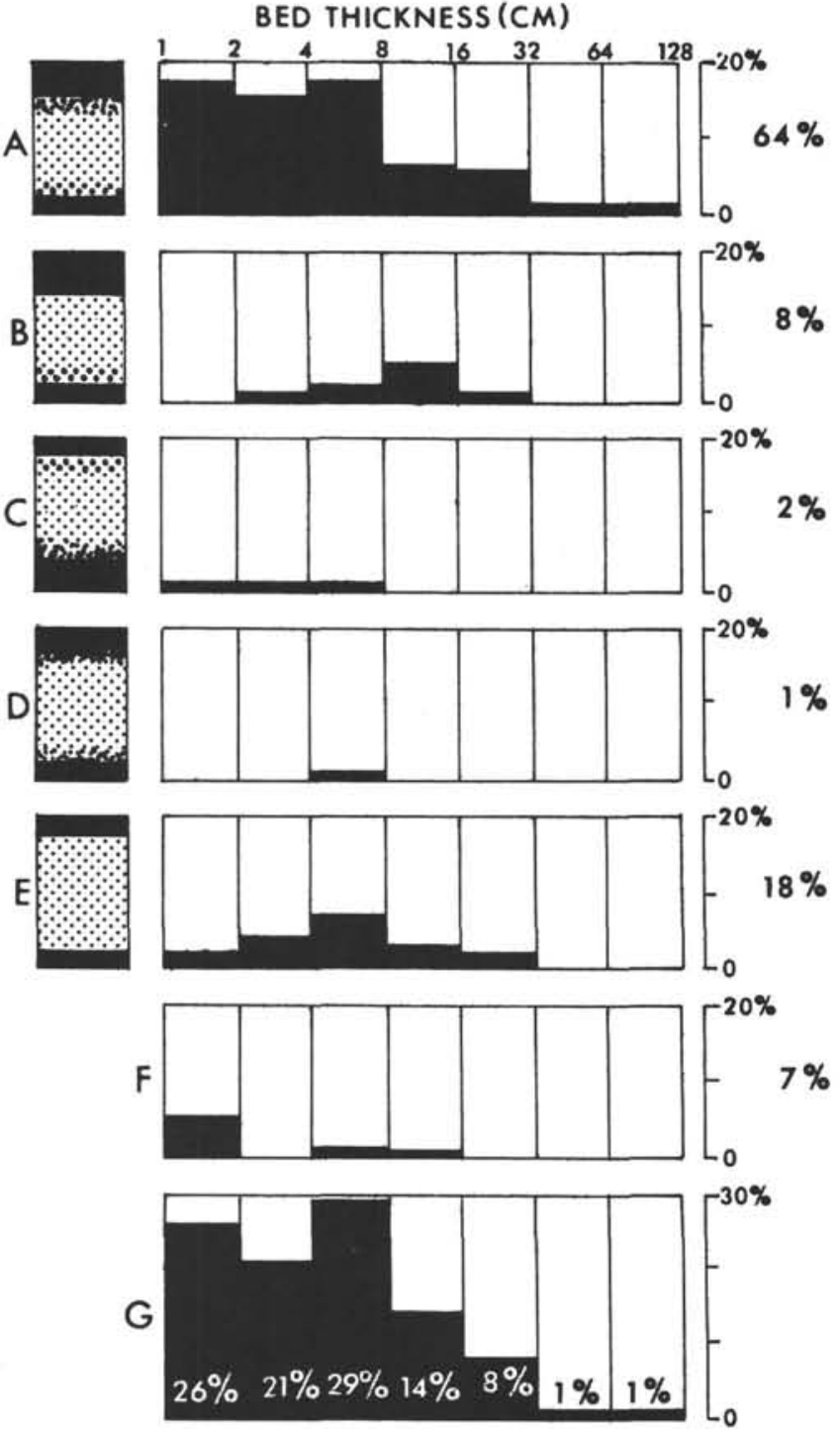

Figure 2. Bed-thickness frequency distribution of the coarser grained intercalations at Site 222. A to F represent beds with different types of grading: $\mathrm{A}=$ normally graded bedded with transitional boundary at the top; $\mathrm{B}=$ normally graded with sharp boundary at the top; $\mathrm{C}=$ inverted grading; $\mathrm{D}=$ symmetrically graded; $\mathrm{E}=$ nongraded $; \mathrm{F}=$ beds with unclear internal structure. The letter $\mathrm{G}=$ general bed-thickness frequency distribution, all categories of beds included. Vertical columns represent bed-thickness classes, expressed in centimeters from 1 to $128 \mathrm{~cm}$. Figures at right: total percentage of each structural category of beds. Frequency based on 148 observed coarse-grained intercalations thicker than 1 $\mathrm{cm}$.

fraction was composed almost entirely of biogenous material, mostly as shell fragments and globigerinid tests. Many of these grains contain pyrite, and this sediment may be related to an outer shelf source by analogy with the work of Schott et al. (1970) (see later discussion). Over one-third of the dominant silt size fraction is fecal pellets and carbonate needles, which X-ray mineralogical data indicate are aragonitic. Discoasters in the nannofossil component, both here and in graded bed II, indicate

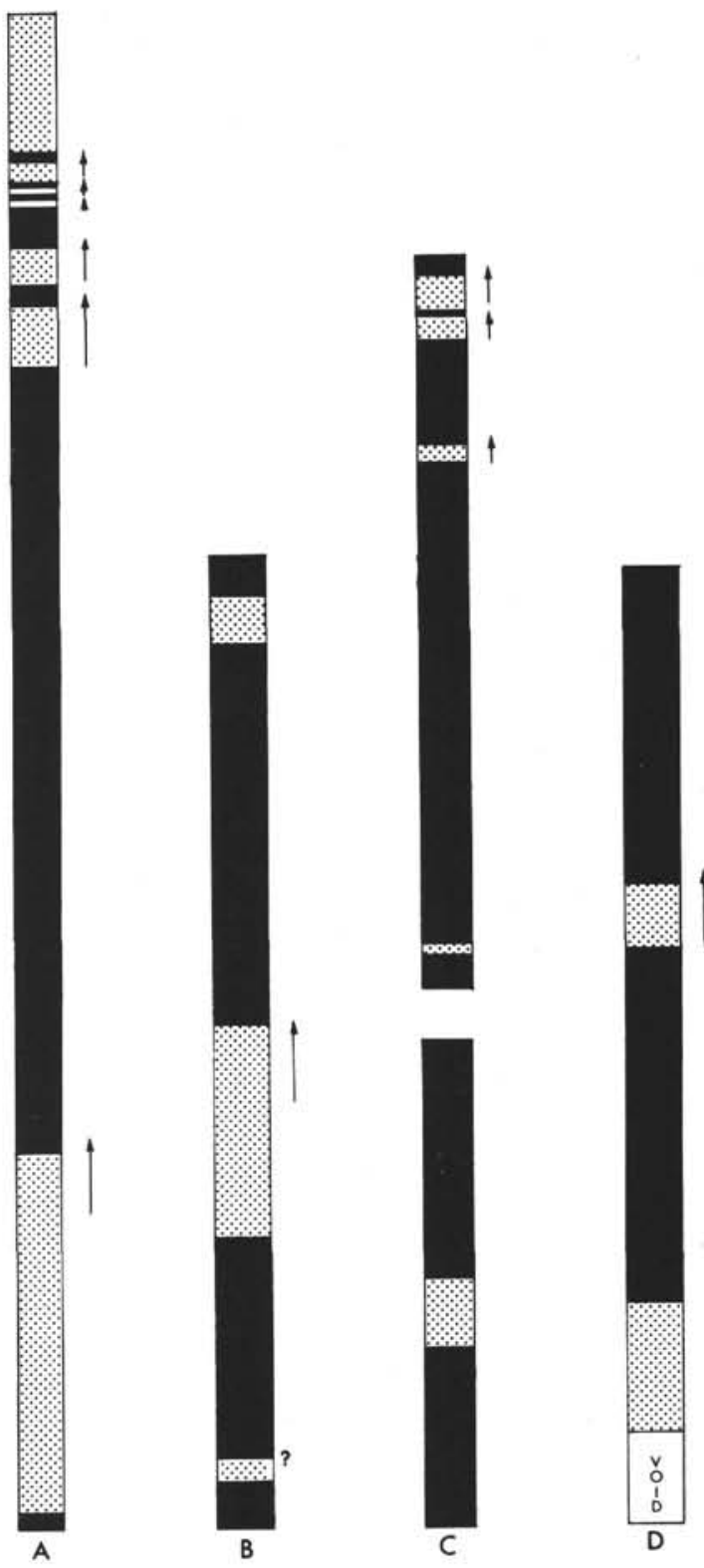

Figure 3. Selected lithologic columns at Site 221. See legend at Figure 1. Location of the columns (core and section): $\mathrm{A}=5-2,5-3$, and $5-4 ; \mathrm{B}=8-1$ and $8-2 ; \mathrm{C}=9-6$ (upper) and 10-3 (lower); and $\mathrm{D}=12-2$. Some sections are only partially represented.

reworking of pre-Pleistocene sediments. The bed, on the other hand, shows many of the characteristics of graded bed I, and these low detrital content beds obviously have a different origin than that of the highly detrital interbed type at Site 221 .

The 60 -cm-thick graded bed IV in Core 12 is the last example selected from Site 221 and is of Pliocene age. The grain-size parameters displayed in Figure 9 show a degree of symmetrical grading, particularly within the silt-size material. The sand composition data show a strong similarity to those of the micaceous graded bed II. Second cycle heavy minerals and abraded carbonate rhombs occur, the latter again indicating a mode of transport mainly in suspension. 


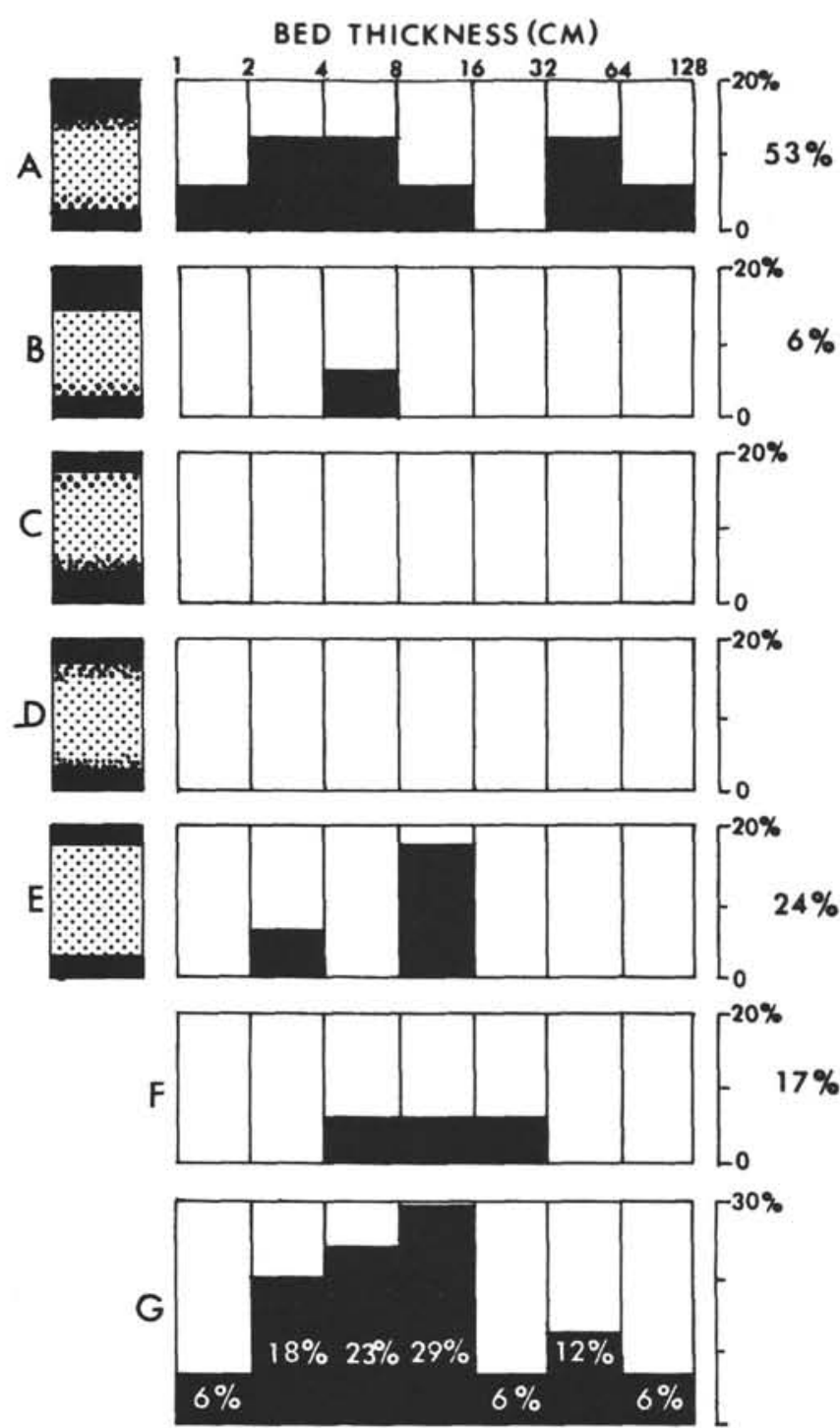

Figure 4. Bed-thickness frequency distribution of the coarser grained intercalations at Site 221. For legend see Figure 2. Frequency is based on only 17 observed beds.

The Upper Pliocene graded bed V was sampled in Core 6 at Site 222. The grain-size analyses by the DSDP shore laboratory confirm the visually apparent grading (Table 6). The sand compositions (Tables 2 and 5) show that the bed is highly terrigenous and micaceous and similar to one of the dominant graded bed type at Site 221 .

Graded bed VI is also of late Pliocene age and encompassed a thickness of over $110 \mathrm{~cm}$. Its grading is obvious from the grain-size plot (Figure 10). Detrital material is dominant in both the sand fractions and the smear slides (Table 2), and even in the latter, heavy minerals were an important feature. The heavy mineralogy is again mainly one of metamorphic type minerals with a minor contribution from an acid igneous source. This assemblage has been typical of all the beds so far described. The identification of very rare (shelf depth) benthic and juvenile planktonic foraminifera near the base of this bed

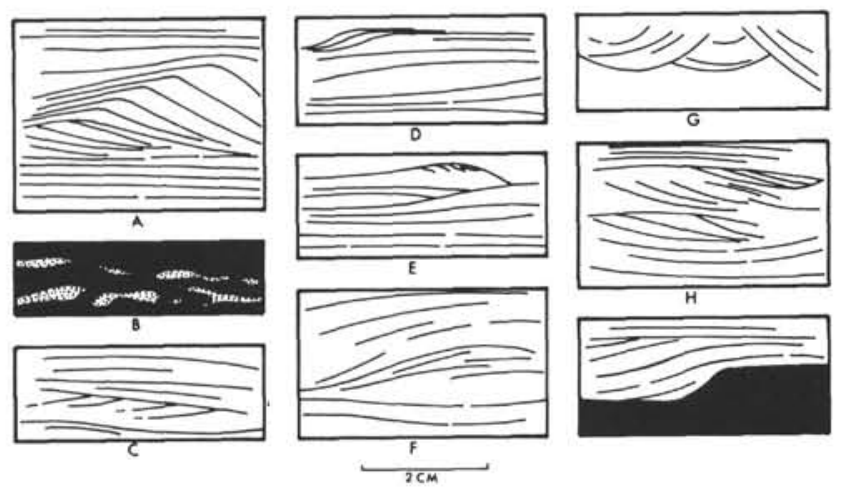

Figure 5. Sedimentary structures shown by some coarser grained intercalations at Site 222 (see text for details). Location of the features (core, section, depth in the section in cm); $\mathrm{A}=34-6,75 \mathrm{~cm} ; \mathrm{B}=27-2 ; \mathrm{C}=23-4,31 \mathrm{~cm}$; $\mathrm{D}=34-6,1-2 \mathrm{~cm} ; \mathrm{E}=34-2,59 \mathrm{~cm} ; \mathrm{F}=23-4,65 \mathrm{~cm}$; $\mathrm{G}=33-2,108 \mathrm{~cm} ; \mathrm{H}=23-4,19 \mathrm{~cm}$; and $\mathrm{I}=34-5,75 \mathrm{~cm}$. Structures shown at $A, C, D, F, G$ and $I$ were observed in graded beds; structures $E$ and $H$ were observed in nongraded beds. $B$ was observed in isolated horizontal laminae.

by $\mathrm{R}$. Fleisher suggests the displacement of faunas from shallower water areas.

The other graded beds were selected from sites to the northwest of Owen Ridge for comparison with those on the Indus Cone.

From Site 223, a Pleistocene-aged graded bed VII was sampled in Core 2. The 100-cm-thick bed has sharp upper and lower boundaries, however, the DSDP shore laboratory analyses confirm the visual estimation of size grading (Table 7). The bed has a strikingly rounded terrigenous sand component, comprising up to two-thirds of its total sand content and contrasts strongly in composition with the beds examined at Sites 221 and 222. The remaining fraction, which is biogenous and consists of pellets, thick molluscan shells, carbonate clasts, and pyrite grains, is probably shelf derived (Table 3 ). Metamorphic and igneous sources for the heavy mineralogy are of about equal importance. Palygorskite in the clay fraction and the frosted texture on the quartz grains suggest an important sediment contribution from nearby desert areas.

Graded bed VIII, at Site 223, which is one meter thick, was sampled from near the top of the Middle Miocene. The DSDP shore laboratory grain-size analyses (Table 8) confirm its grading, while its sand composition is similar to that of graded bed VII from the Pleistocene (Table 3) except that, texturally, only some of the terrigenous material is rounded.

The bed sampled at Site 224 (graded bed IX) occurs in the Middle Oligocene of Core 8 . The DSDP shore laboratory analyses show that the grading is repeated twice within the $50 \mathrm{~cm}$ thickness of the bed (Table 9). Compositional analysis (Table 4) revealed the similarity of this bed to the detrital type Indus Cone beds in its mica/quartz dominated detrital fraction, its high percentage of metamorphic minerals and rock fragments, its relatively low content of acid igneous derivatives, and its generally low biogenous content. 
TABLE 5

Heavy Mineral Counts

\begin{tabular}{|c|c|c|c|c|c|c|c|c|c|c|c|}
\hline \multirow{3}{*}{$\begin{array}{l}\text { Core, Section, } \\
\text { Interval }(\mathrm{cm})\end{array}$} & \multicolumn{3}{|c|}{ Site 221} & \multicolumn{5}{|c|}{ Site 222} & \multicolumn{2}{|c|}{ Site 223} & \multirow{2}{*}{ Site 224} \\
\hline & $5-4$ & $8-2$ & $12-2$ & $6-4$ & $8-4$ & $9-4$ & $9-4$ & $28-5$ & $2-3$ & $19-2$ & \\
\hline & $46-48$ & $83-85$ & $61-63$ & $133-135$ & $68-70$ & $25.5-27.5$ & $89-91$ & $93-94.5$ & $38-39$ & $140-142$ & $28-29$ \\
\hline Kyanite & 1 & 4 & - & 8 & - & 3 & 6 & 5 & 28 & 29 & 12 \\
\hline Garnet & 4 & 10 & 2 & 17 & - & 2 & 49 & 30 & 26 & 6 & 45 \\
\hline Zircon & 1 & 2 & 3 & 3 & 3 & 1 & 5 & 2 & 18 & 5 & 14 \\
\hline Tourmaline & - & 1 & - & - & - & - & - & - & - & 4 & 3 \\
\hline Phos. Mins & 1 & 4 & 1 & 2 & - & 2 & 1 & 6 & 40 & 5 & 9 \\
\hline Others & - & - & - & 2 & - & 11 & 5 & 4 & 11 & 2 & 1 \\
\hline Actinolite & 3 & 10 & 2 & 6 & 6 & - & 6 & 8 & 4 & 20 & 41 \\
\hline Blue/Grn Hbld & 32 & 61 & 2 & 208 & 8 & 75 & 212 & 232 & 56 & 80 & 124 \\
\hline Brn. Hbld. & 3 & 8 & - & 10 & 1 & 14 & 44 & 30 & 46 & 26 & 28 \\
\hline Epidote & 4 & 4 & - & 8 & - & 3 & 7 & 10 & 24 & 4 & 18 \\
\hline Clinozoisite & 1 & 4 & 1 & 2 & - & 3 & 1 & - & 14 & 6 & 3 \\
\hline $\begin{array}{l}\text { Total Diagnostic } \\
\text { Grains }\end{array}$ & 50 & 108 & 11 & 266 & 18 & 114 & 336 & 327 & 267 & 187 & 298 \\
\hline $\begin{array}{l}\text { Total Grains } \\
\text { Counted }\end{array}$ & 420 & 440 & 362 & 410 & 400 & 840 & 840 & 532 & 930 & 650 & 950 \\
\hline
\end{tabular}

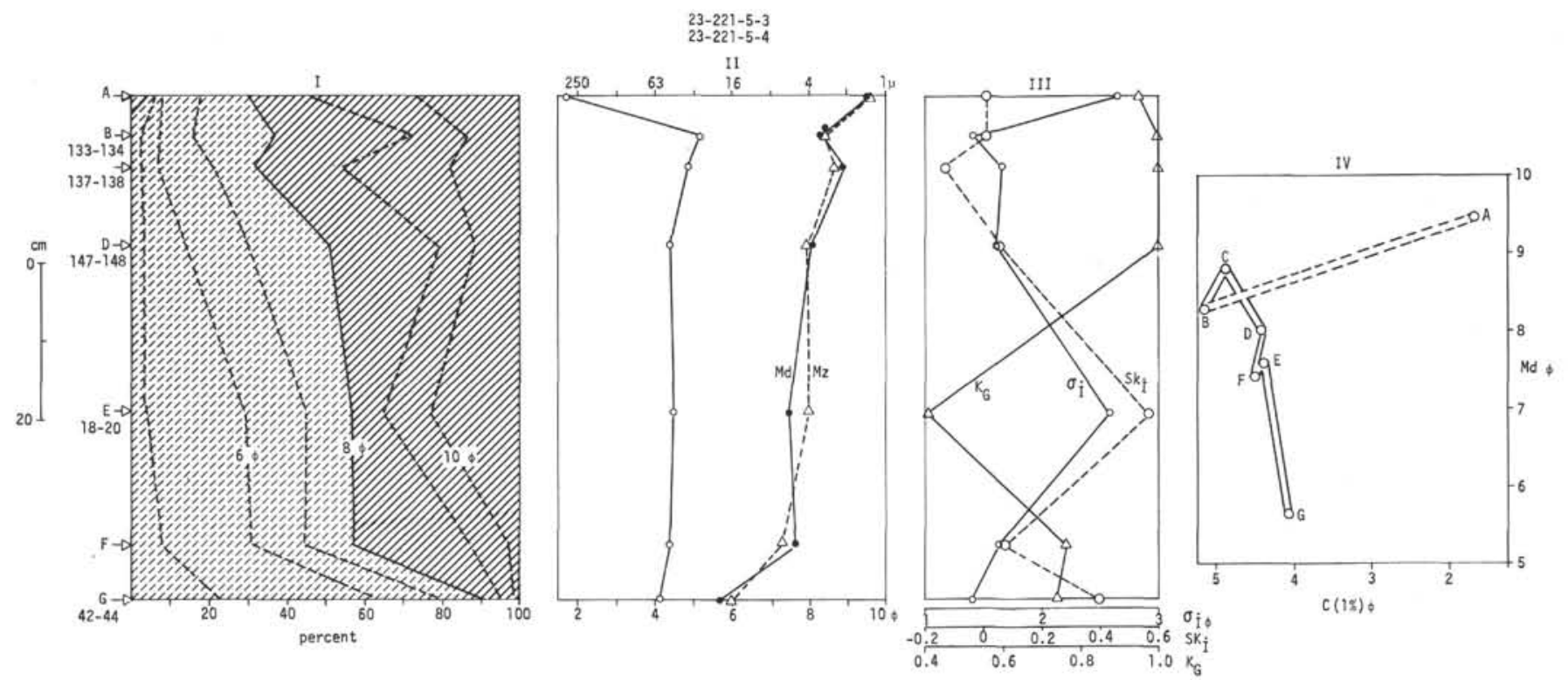

Figure 6. Graded bed I (221-5-4, $47 \mathrm{~cm}$ to 221-5-3,126 cm). Arrows at the left of diagram indicate sampling points. Samples are identified with capital letters (for comparison with the C/Md diagram at the right). Their position in the core-section is also indicated. I-Vertical grain-size variation in phi units. Bottom scale in percentages. II-Vertical variation of the C index (see definition below), median (Md) and graphic mean (Mz). Scale expressed in phi units at the bottom and in microns at the top of the diagram. III-Vertical variation of the inclusive graphic standard variation $(\sigma \mathrm{I})($ in phi units), inclusive graphic skewness $\left(\mathrm{Sk}_{\mathrm{I}}\right)$ and graphic kurtosis $\left(\mathrm{K}_{\mathrm{G}}\right)$. Different scales for each parameter. IV-C/Md diagram. C (bottom scale in phi units) = grain size corresponding at the coarsest 1 percent on the cumulative size curve; represents an index of the competency of the transporting agent. Md (vertical scale, in phi units) = median diameter. The curve on this diagram reflects the existence of grading, its extension (degree of separation), type, and unity. Solid and dashed lines differentiate sedimentary units. 

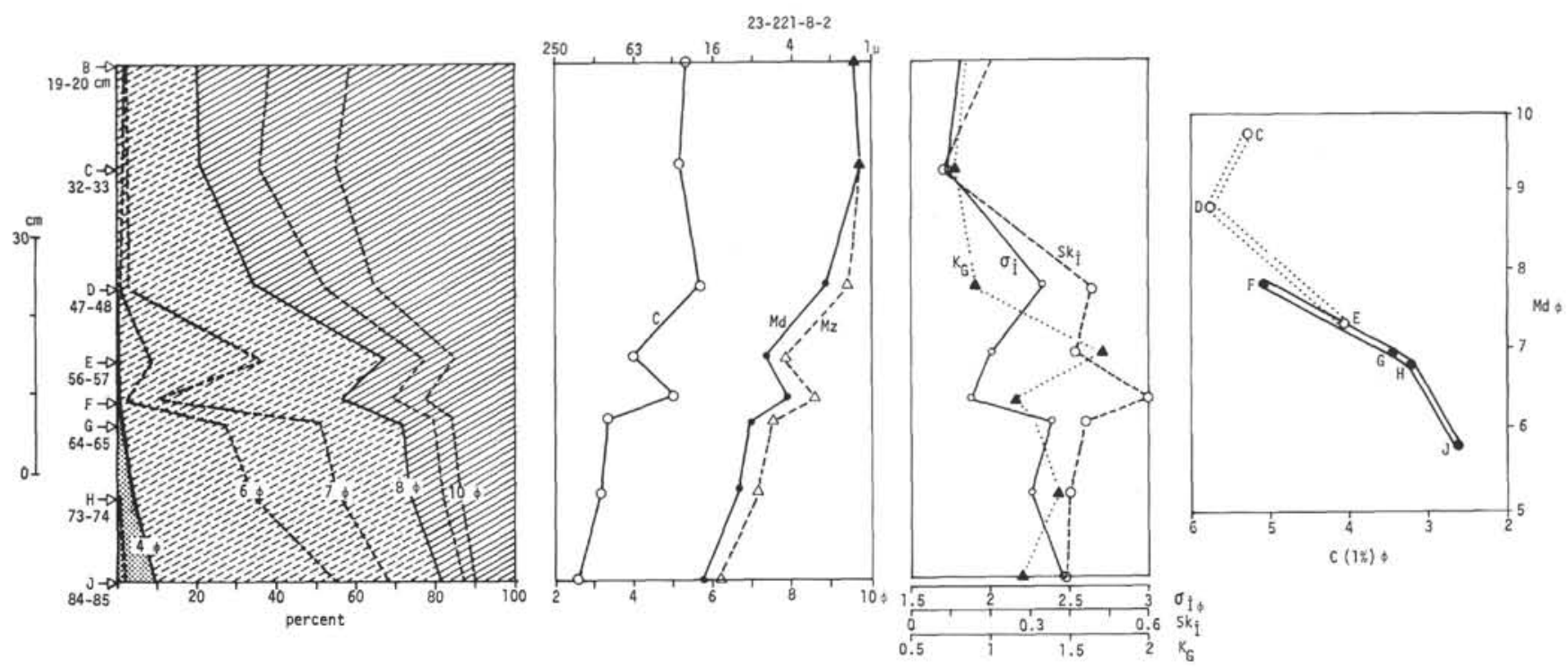

Figure 7. Graded bed II (221-8-2, 86-15 cm). For legend see Figure 6.
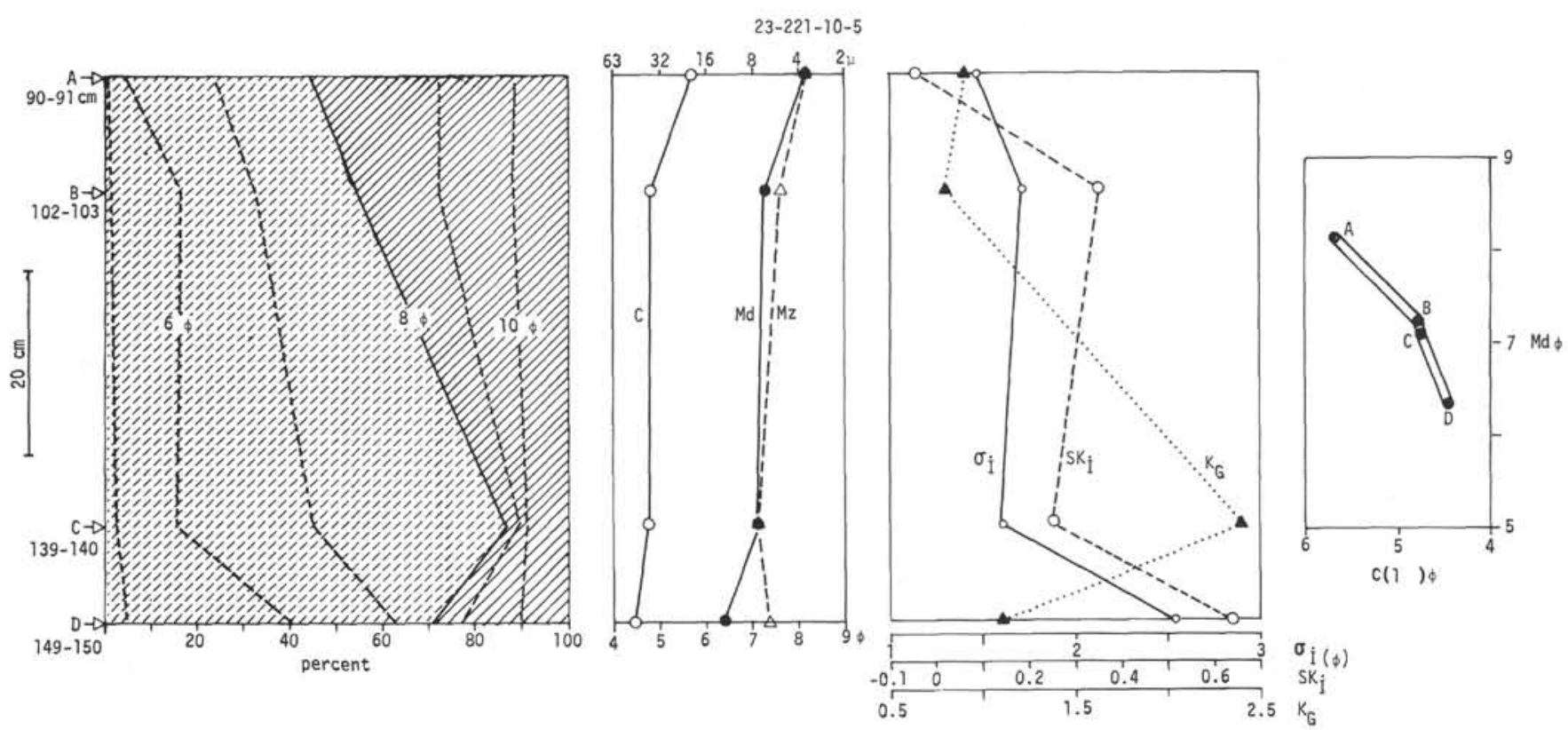

Figure 8. Graded bed III (221-10-6, $8 \mathrm{~cm}$ to 221-10-5, $90 \mathrm{~cm})$. For legend see Figure 6.

\section{Nongraded Beds}

The apparent lack of grading in these beds was checked, in most cases, by the examination of smear slides. Only one nongraded bed was selected for detailed compositional and textural studies. A number of other nongraded beds can be described from information derived in composition studies.

Nongraded beds I and II are from the Upper Miocene section at 222-28-5, which contains a number of thin nongraded sandy beds. Bed I is unconsolidated, while bed II is a fully lithified calcareous sandstone. Grain-size analyses were carried out on bed I only (Figure 11), and this confirms its nongraded nature. Sand compositions of the beds (Tables 2 and 5) are very similar to one another except for bed II having a micrite cement. The heavy mineral content indicates a dominant metamorphic provenance with a secondary acid igneous influence as in the graded beds at this site, but the presence of barkevikite suggests a slight basic igneous contribution also. Mica and chlorite dominate the detrital fraction as in the graded beds.

The Pleistocene nongraded bed III from Site 221 (Core 6) was examined by smear slides only. It was found to be dominated by a quartz/feldspar-rich detrital fraction with heavy minerals, including rounded carbonate rhombs, and mica. For this site, the mica is of unusually minor importance for a bed having such a strongly detrital nature. 

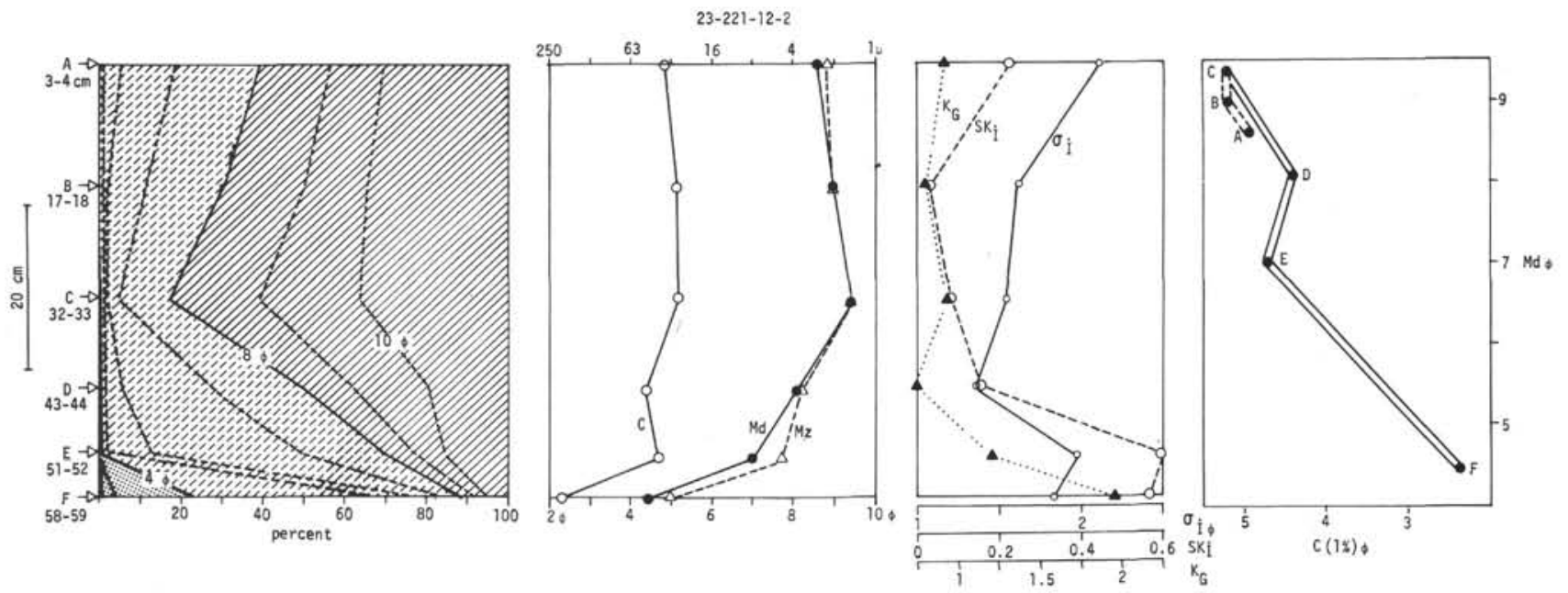

Figure 9. Graded bed IV (221-12-2, 63-3 cm). For legend see Figure 6.

TABLE 6

DSDP Grain-Size Determinations, Site 222 (Graded Bed V)

\begin{tabular}{lccr}
\hline $\begin{array}{l}\text { Core, Section, } \\
\text { Interval }(\mathrm{cm})\end{array}$ & $\begin{array}{c}\text { Sand } \\
(\%)\end{array}$ & $\begin{array}{l}\text { Silt } \\
(\%)\end{array}$ & \multicolumn{1}{c}{$\begin{array}{l}\text { Clay } \\
(\%)\end{array}$} \\
\hline $6-4,116-118$ & 0.0 & 45.6 & 54.4 \\
$6-4,120-122$ & 0.0 & 59.6 & 40.4 \\
$6-4,127-129$ & 0.3 & 90.7 & 9.1 \\
$6-4,136-138$ & 2.1 & 95.4 & 2.5 \\
\hline
\end{tabular}

TABLE 7 DSDP Grain-Size Determinations, Site 223 (Graded Bed VII)

\begin{tabular}{lrrr}
\hline $\begin{array}{l}\text { Core, Section, } \\
\text { Interval }(\mathrm{cm})\end{array}$ & $\begin{array}{c}\text { Sand } \\
(\%)\end{array}$ & $\begin{array}{l}\text { Silt } \\
(\%)\end{array}$ & $\begin{array}{l}\text { Clay } \\
(\%)\end{array}$ \\
\hline $2-2,41-43$ & 1.9 & 45.1 & 53.0 \\
$2-2,92-94$ & 18.7 & 73.1 & 8.2 \\
$2-2,128-139$ & 51.9 & 40.0 & 8.1 \\
$2-3,6-8$ & 53.6 & 37.8 & 8.6 \\
$2-3,34-36$ & 54.0 & 33.9 & 12.1 \\
\hline
\end{tabular}
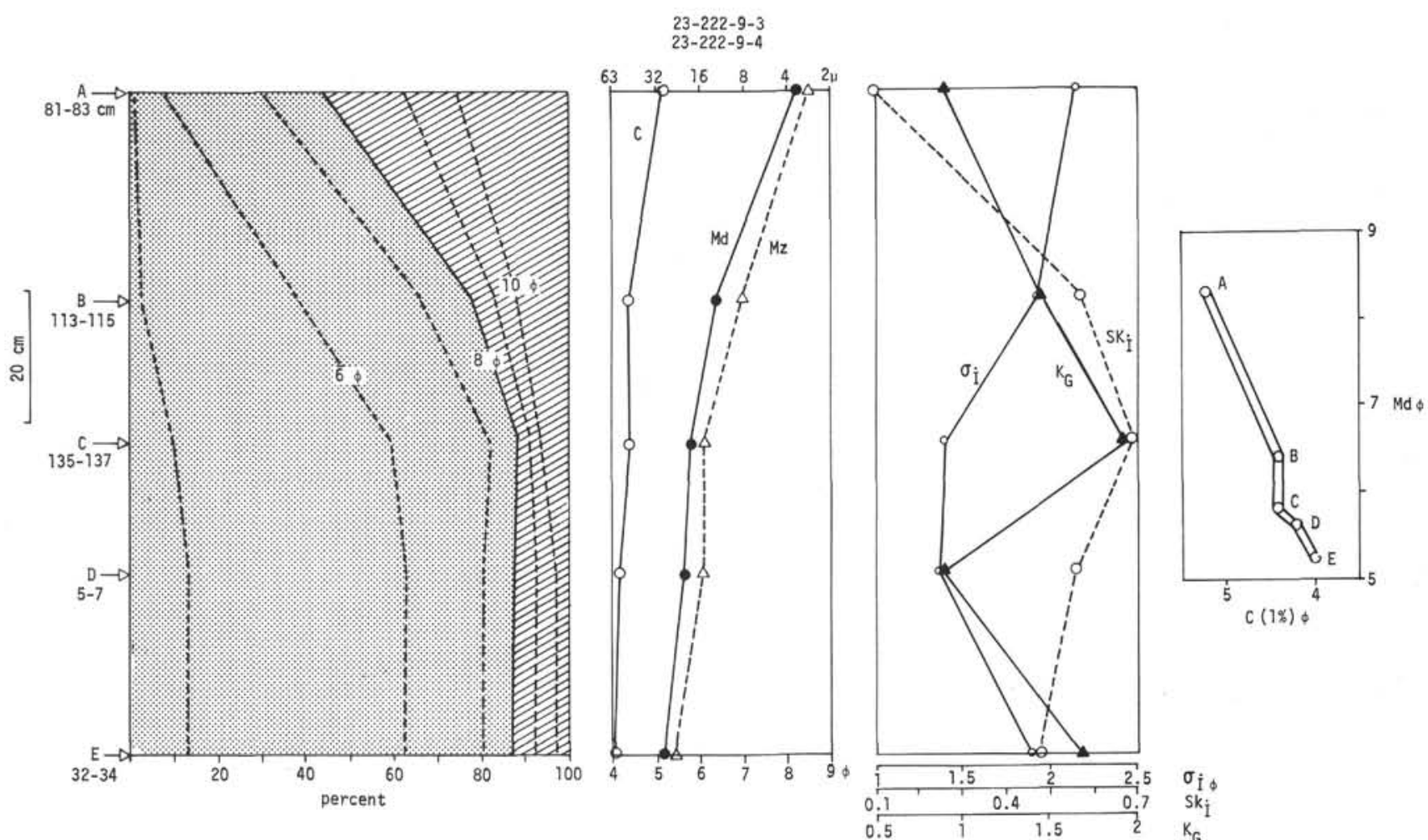

Figure 10. Graded bed VI (222-9-4, $40 \mathrm{~cm}$ to 222-9-3, $80 \mathrm{~cm})$. For legend see Figure 6. 
Other nongraded beds were examined at Site 224. These were calcareous sandstones of composition similar to nongraded beds I and II.

\section{Individual Laminae}

Generally at Sites 221 and 222, sand-size sediment occurs in beds greater than $1 \mathrm{~cm}$ thick. Nevertheless, some individual laminae do occur, most of which are composed solely of sand-size grains of detrital material. A specific example is the single lamina at $70 \mathrm{~cm}$ in the Upper Miocene section of 222-9-2, which is a well-sorted detrital sand intercalation containing about 20 percent carbonate fragments.
TABLE 8

DSDP Grain-Size Determinations, Site 223 (Graded Bed VIII)

\begin{tabular}{lrcc}
\hline $\begin{array}{l}\text { Core, Section, } \\
\text { Interval }(\mathrm{cm})\end{array}$ & $\begin{array}{c}\text { Sand } \\
(\%)\end{array}$ & $\begin{array}{c}\text { Silt } \\
(\%)\end{array}$ & $\begin{array}{l}\text { Clay } \\
(\%)\end{array}$ \\
\hline $19-2,41$ & 0.2 & 47.0 & 52.8 \\
$19-2,58$ & 0.6 & 53.1 & 46.4 \\
$19-2,98$ & 1.7 & 84.7 & 13.6 \\
$19-2,145$ & 27.2 & 55.9 & 16.8 \\
\hline
\end{tabular}

TABLE 9

DSDP Grain-Size Determinations, Site 224 (Graded Bed IX)

\begin{tabular}{lccc}
\hline $\begin{array}{l}\text { Core, Section, } \\
\text { Interval }(\mathrm{cm})\end{array}$ & $\begin{array}{l}\text { Sand } \\
(\%)\end{array}$ & $\begin{array}{l}\text { Silt } \\
(\%)\end{array}$ & $\begin{array}{l}\text { Clay } \\
(\%)\end{array}$ \\
\hline $8-5,13$ & 0.0 & 58.6 & 41.4 \\
$8-5,18$ & 6.1 & 57.8 & 26.0 \\
$8-5,26$ & 9.3 & 68.8 & 21.8 \\
$8-5,32$ & 0.1 & 50.4 & 49.5 \\
$8-5,41$ & 3.1 & 72.1 & 24.8 \\
$8-5,45$ & 4.3 & 70.0 & 25.7 \\
$8-5,52$ & 8.4 & 71.6 & 20.1 \\
\hline
\end{tabular}

\section{The Dominant Fine-Grained Lithologies}

At Site 221, the silt and sand interbeds occur within cores of Pleistocene to Miocene age. Down to 111 meters (unit I), the dominant lithology is a fine-grained greenish nanno ooze. Nannofossil content, determined from smear slides, is always greater than 50 percent of the total sediment, and in most slides, nannofossils accounted for over 70 percent. The nonfossiliferous component is dominated by mica or clay minerals with accessory quantities of fine micarb or other clay-size material. Other unit I smear slides near the silty beds contain greater amounts of detrital material and there the nannofossil content drops to between 50 and 70 percent. Their nonfossiliferous components are substantially the same, that is, high in mica and clay minerals, but silt-size detrital material, especially quartz and feldspar, appears, and coarse micarb is prominent. The association of coarse interbeds with higher detrital-content fine-grained lithologies is further demonstrated by Core 6 in which only isolated thin coarse horizons occur. Here, intercalations of fine sediment occur within the greenish ooze-dominated lithology which are gray in color and have a greater detrital content.

In contrast, the unit II background lithology contains only traces of nannofossils, due to its deposition below the calcite compensation depth (see Chapter 5). The sediment is olive gray in color, and compositionally, it is made up mainly of clay-size mica and chlorite (over $50 \%$ ). Quartz is next in importance (about 20\%), followed by micarb, feldspar, dolomite, and plant debris.

At Site 222 , the dominant fine-grained sediments display a greater variety of lithologic types (see Table 3, Site Chapter 6 , this volume, back pocket). The two major finesediment types recovered are (a) biogenous greenish clays and silty clays, and (b) detrital gray silty clays.

The gray sediments are by far the most common, representing about 80 percent of the lithologic sequence at Hole 222. The green sediments appear at different levels within the prevailing gray sediment, usually in thinner $50-\mathrm{cm}$ to 20 -cm-thick intervals except for a thick surface interval.
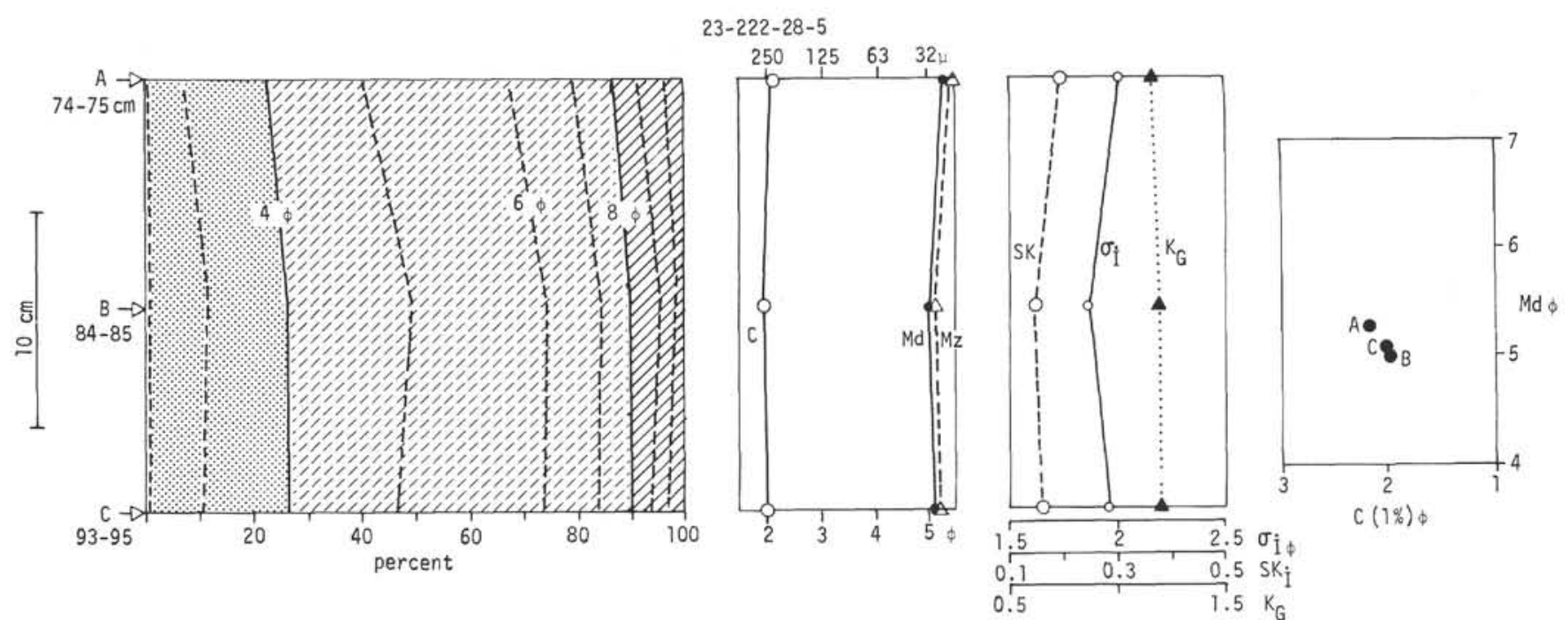

Figure 11. Nongraded bed 222-28-5, 97-74 cm. For legend see Figure 6. 
The green facies is characterized by a relatively high content of nannofossils (up to 70 percent) together with a minor detrital component which is similar to the clay-size material of the gray background lithology described below. These green nanno oozes are somewhat similar to the greenish intervals between the unit I silty beds of Site 221 .

The gray sediments are almost totally detrital in character, containing only a small amount of nannofossil material. Mica makes up nearly half of the detrital fraction, with quartz next in importance, and 5 to 17 percent micarb particles. These clastic components are mostly in the clay-size range, e.g., smear slide (S.S.) $222-34-1,81 \mathrm{~cm}$.

Some transitional lithologic types between the two facies occur; for example, a fine-grained gray clayey sediment with high nannofossil content and green high detrital clay lithology.

According to analyses by J. Boudreaux, the biogenous greenish facies contain only indigenous nannofossils. In contrast, the gray sediments contain a mixed assemblage of indigenous and reworked species. Some gray deposits contain reworked fossils almost entirely with very few indigenous forms (Figure 12).

seem to belong to the Pascichnia ichnological group representing traces left by mud-ingesting organisms. In contrast, the gray detrital sediments often show welldefined bedding, particularly near silty interbeds and

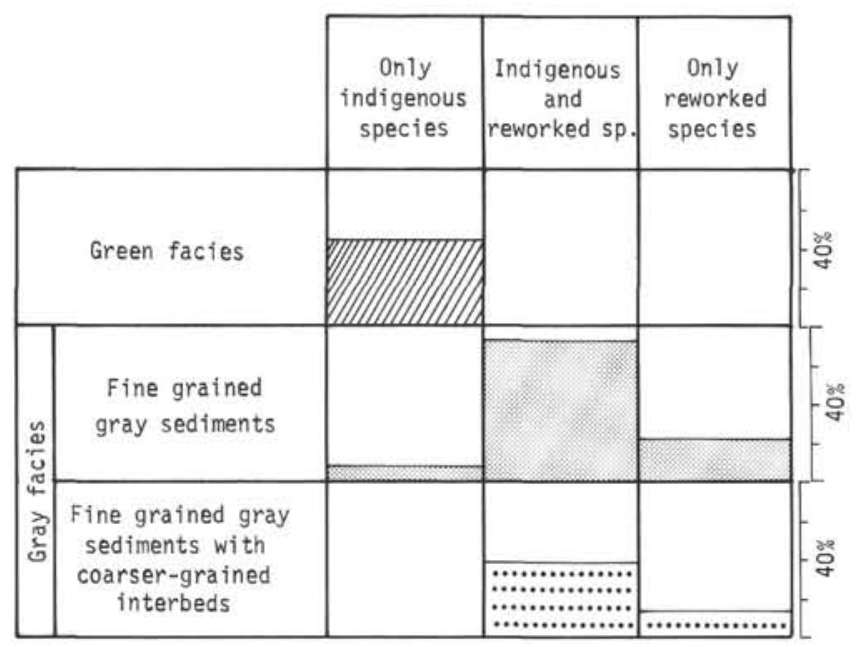

Figure 12. Distribution of the indigenous and reworked species of nannofossils in the clayey sediments at Site 222. Based on data supplied by Boudreaux (this volume). Percentages of total number of analysis.

No significant difference seems present in the distribution of foraminifera, according to analyses by R. Fleisher. Both facies contain resedimented neritic and/or uppermiddle bathyal benthics, reworked Eocene benthics, and in situ deep benthonic and planktonic species.

With the exception of the uppermost green interval, the green sediments are characterized by intense bioturbation but contain no obvious bedding or current structures. The burrow structures are mostly horizontal in orientation and laminae, but rarely show burrow structures. In addition, there are long intervals within the gray facies apparently devoid of bedding structures or containing, at most, rare laminae. Burrow structures are observed to terminate abruptly against green facies contacts with the gray facies.

The sand, silt, and clay ratios of the two major fine-sediment lithologies are remarkably similar. Both contain between 60 and 80 percent clay and between 20 and 40 percent silt. On cumulative curves, the grain-size distributions of both green and gray sediments outline two populations (Figure 13). The $\mathrm{C} / \mathrm{Md}$ diagrams (after Passega 1964), show that the gray sediments outline a field that seemingly is a continuation of that of the coarse interbeds. The green material, on the other hand, may delineate a separate field (only three samples) (see Figure 14).

Due to their nannofossil content, the green sediments have a higher $\mathrm{CaCO}_{3}$ content ( 40 to $60 \%$ ) than the gray sediment, which averages only 15 percent $\mathrm{CaCO}_{3}$. The organic carbon content varies markedly in both green and gray sediments, mostly between 0.3 and 0.4 percent. Exceptionally high organic carbon values (up to $2.0 \%$ ) are present only in the uppermost green biogenous sediments.

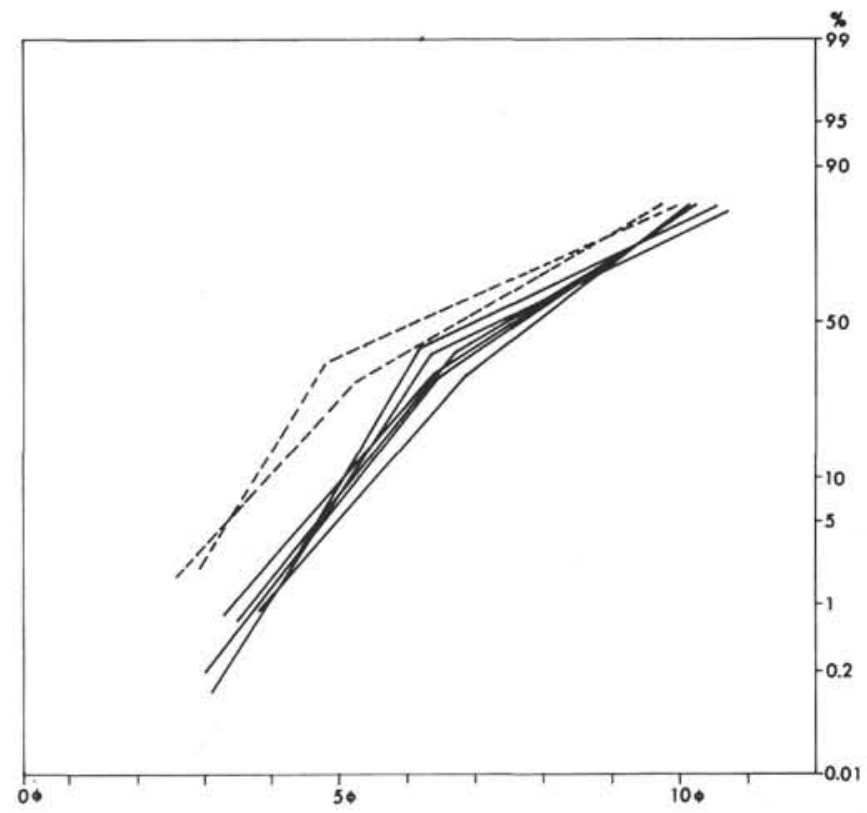

Figure 13. Simplified grain-size cumulative curves of samples from the greenish (dashed lines) and gray (solid lines) facies at Site 222. Each segment represents a grain-size population.

\section{DISCUSSION}

\section{Environment of Deposition}

According to analyses made by Fleisher (see biostratigraphic summaries of Sites 221 and 222, this volume), the rather scarce forminiferal assemblages of Site 222 and of Site 221 , Cores 1 to 12 , contain in most cases, besides 


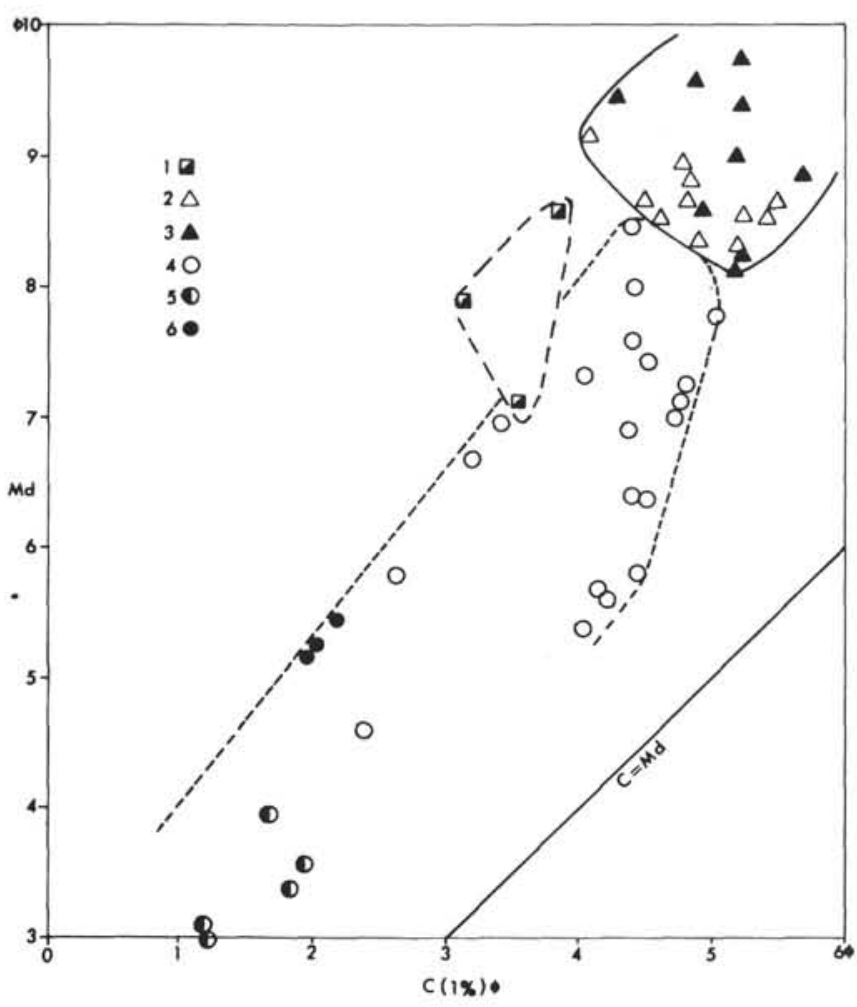

Figure 14. C/Md diagram. Includes samples from clayey sediments at Site 222 and coarser grained intercalations at Sites 221 and 222. $\mathrm{C}$ (in phi units) = grain size corresponding at the coarsest 1 percent on the cumulative size curve (Passega, 1964). Md (in phi units) = median diameter. Types of samples: 1 = green facies silty-clay (Site 222); 2 = gray facies silty-clay (Site 222); 3 = same as (2) but taken just above graded beds; $4=$ graded beds (Sites 221 and 222); 5 = possible graded, sandy beds (Sites 221 and 222); and 6=nongraded bed (Site 222).

planktonics, benthonic forms largely of deep-water origin. This is a strong indication that the Indus Cone sedimentation developed continuously in a deep-water environment.

\section{Provenance of the Deep-Sea Sand Particles}

The coarse-grained interbeds with nonindigenous silt and sand-size material are obviously out of place in an abyssal environment. Ostracods and pteropods generally indicate shelf to upper continental slope origin, and thick molluscan shell debris and plant material are indicative of an inner shelf to littoral environment. The aragonitic fecal pellets and needles, which are particularly prominent in some of the graded beds, were encountered by Stackelberg (1972) while piston coring the western Indian shelf. He believed that they resulted from Pleistocene low stands of sea level (i.e., they are again of distinctly shallow-water origin). Where pyrite is found within the tests of planktonic and nonindigenous benthonic foraminifera, it could possibly be assigned to a source on the outer shelf or upper continental slope. This would be in accordance with the zone of low oxygenation and reduced bottom sediments in these depths today (Schott et al., 1970). Fleisher (personal communication) has pointed out that some interbeds contain rare shallow-water foraminifera represented by neritic benthics and juvenile planktonics.

The available literature on the areas marginal to the Indus Cone indicates likely sources of the interbedded coarse sediments. It must be pointed out that direct comparisons with published studies on marine sediments cannot be made, as they only deal with sediments of Holocene and sometimes late Pleistocene age.

In spite of this constraint, some very relevant information can be gained by considering further the bottom deposit facies outlined by Stackelberg (1972) for the India/Pakistan continental margin. He shows that the facies zones pass seawards from inshore mineral sands through micaceous muds, pteropod muds, and relict sands (including aragonite and biogenous material of former lower sea levels in the Pleistocene) into a fine mud facies on the Cone itself. This would indicate that most of the nonindigenous sand found in the Indus Cone sequences could have been derived from along this shelf.

Certain morphological considerations set limits as to how much of this long shelf area could have contributed such components. The Laccadive-Maldive Ridge was shown by Stackleberg (1972) to be an effective barrier against sandy sediment of terrigenous type reaching the Cone anywhere south of about $14^{\circ} \mathrm{N}$. The Murray Ridge system has a similar effect to the north and west of $25^{\circ} \mathrm{N}$ (around Karachi). This leaves a long "exposed" shelf capable of contributing sandy sediments about $1,120 \mathrm{~km}$ long.

The mineral analyses help to narrow the tield of derivation for terrigenous components still further. Beiersdorf (1972) has shown a sharp contrast in the heavy minerals within the nearshore sand facies zone. This is between the sand-size heavy minerals of the Indus Delta Front, with its associated area extending southeast as far as $23^{\circ} \mathrm{N}$, and those of the area immediately north of the delta, which is under the influence of a small number of minor rivers. Characteristic of the latter area is a dominance of opaque minerals with amphiboles, at times alternating with garnet, next in importance. The Indus Front sediment has a predominantly metamorphic provenance and always contains amphiboles as the dominant heavy mineral; also, opaques are invariably more abundant than garnet. A core taken by Stewart et al. (1965) off the Gulf of Kutch has a heavy mineral assemblage with typical Indus characteristics. However, others taken farther south (off the Gulf of Cambay) in the same study, have assemblages similar to those north of the Indus mouth except for a stronger influence of basic igneous derivatives. All other major rivers of the Indian West Coast, other than the Indus, debouch into the Gulf of Cambay. The basic igneous derivatives there are probably from the Deccan Trap areas of the hinterland. South of the Gulf of Cambay and north of the Laccadive Ridge, the hinterland is dominated by the Deccan Trap system, but the major drainage is to the Bay of Bengal.

Taking all this information into account, it is almost certain that the coarser grained deposits with relatively high terrigenous content at Site 221 and all those examined at Site 222 have entered the sea at the Indus River mouth. 
Transport was probably by way of the Swatch Submarine Canyon and the extensive leveed channel system beyond it.

The calcareous interbeds with low terrigenous content and made up mostly of shallow-water shell debris and aragonite (fecal) pellets, could have originated anywhere along the exposed portion of the shelf. Some, however, still show their source by their mineralogic content. For example, the graded bed in Core $221-5$ has a mineralogy indicating its source was probably near the Indus delta front shelf region. Others have high montmorillonite content in contrast to the low values of Indus derived beds. Presumably, this reflects the effect of the Deccan Traps and precludes any derivation from near the Indus Front.

The graded bed with an exceptionally low content of coarse terrigenous material in Core 221-10-6 could even have been derived from the Laccadive-Maldive Ridge itself. A similar bed was described by Stackelberg (1972) in Holocene sediments near this site. His line of cores continued landward to show a damming of coarse layers of terrigenous type behind the ridge. Also at Site 220, thin graded foram shell sands were recovered with no terrigenous coarse fraction but with reworked nannofossils. No aragonitic sediments were reported, though, from Site 220 , nor have they been described around the ridge atolls to the east.

The other coarse sediment beds recovered at Sites 221 and 222 , the nongraded beds and individual laminae, are probably also dominantly Indus-derived. The graded beds at Site 222 in Cores 28, 29, 30, 33, and 34 are interspersed with nongraded beds, a number of which are lithified calcareous sandstones. In all cases, the mineralogy of their sands is similar to that of sands on the shelf off the Indus Delta. The minor basic igneous influence present in the heavy mineralogy, though, may possibly indicate a western source (as is discussed below).

Throughout the Pleistocene and Pliocene section at Site 223, sandy intercalations of shell debris with some terrigenous material are found, though they are most prominent in the upper few cores. The Pleistocene graded bed in Core 2 was characterized by pellets, thick coral and molluscan shell fragments, neritic and upper bathyal forams, carbonate rhombs, and pyrite contained in shell tests. In some respects it is similar to the shelf-derived detritus found at the Indus Cone sites but is distinctive for its well-rounded mineral grains, and its indicators of eolian conditions ("frosted" quartz grains and palygorskite in the clay mineralogy). Overall, the composition is more similar to those relict Pleistocene shelf sediments described by Sarnthien (1971) from the Persian Gulf and Gulf of Oman. The heavy mineralogy of this bed is the only sample analyzed which indicates a major contribution from three types of provenance - metamorphic, acid igneous, and basic igneous - all of which are present in the Oman hinterland and were similarly represented in the Muscat beach sands (see Chapter 11, this volume).

No other graded beds were cored at Site 223 except for one in the Middle Miocene interval. The graded bed there lacks the striking roundness, pellets, and plant fragments of the Pleistocene material and in this manner is more similar to the sands at Site 222. Fine-grained globular pyrite occurs; the heavy minerals show less basic igneous influence, and carbonate content is relatively low.
At Site 224, the Middle Oligocene graded bed sampled in Core 8 , Section 5 is one of a number of similar coarse horizons in the core. It is characterized by a particularly low biogenous content, a relatively high percentage of metamorphic rock fragments, and a general dominance of mica and chlorite over quartz and feldspar. The sand there has a more abundant and varied heavy mineralogy than any of the other beds samples. Since the background sediments can be demonstrated to have been deposited below the calcite compensation depth, the low biogenous content can be partly explained. The sediment still has a more terrigenous aspect than the beds cored at Site 223. A reconstruction of the Oligocene topography of the western Arabian Sea indicates shallower water areas lying to the north and west of site which could have been a possible source for those coarse-grained layers. A strong degree of similarity in composition with the Indus Cone beds also exists. The site at that time however, would probably have been at a shallower depth than the sea floor on the Indus Cone. Therefore, an Indus River source can possibly be discounted. In view of the upper Oligocene sand at this site and the Middle Miocene sand at Site 223 showing similarities to those of Indus derivation, it is interesting to speculate whether the basic igneous components in the upper Miocene sands at Site 222 could have a western source. This raises the possibility of currents carrying sand occasionally breaching the MurrayOwen-Ridge system, which may not have been such an effective barrier at that time.

\section{Relative Importance of Sand Components}

From this investigation, it is possible to give some indication of the relative importance of sand-sized components in the Arabian Sea sediments and also to give an opinion as to the relative importance of contributors to the overall sedimentation processes. Land-derived detritus in the sediments is more common than pelagic material which is not surprising when one considers that landmasses bound three sides of the Arabian Sea. Some of this land-derived material, particularly at Sites 222, 223, and 224 in the northwestern Arabian Sea, may have experienced eolian transport. Goldberg and Griffin (1970) estimated the eolian contribution to the Arabian Sea as 0.8 $\times 10^{14} \mathrm{~g} / \mathrm{yr}$, as opposed to an estimated $4 \times 10^{14} \mathrm{~g} / \mathrm{yr}$ brought in by the Indus River. However, the eolian dust contribution to the northern Indian Ocean is still not as high as that brought to the North Atlantic by the "trade" winds (Aston et al., 1973).

In analyzing the nature of the source terrain, the area drained by rivers flowing to the Arabian Sea is predominantly one of sedimentary rocks. In the coarse fraction, however, sedimentary rock constituents were much less abundant than might be expected, suggesting that they were depleted during fluvial transport. Some carbonate rhombs survived, presumably due to density current transport, and second cycle heavy minerals occur in the form of rounded garnet and zircon grains. The heavy mineralogy, particularly that of the Indus Cone cores, is dominated by a metamorphic assemblage which is confirmed by the quartz textures and rock fragments. The Cone sediments show the secondary influence of an acid igneous assemblage, but it is only at drill sites to the north and west of the Murray-Owen-Chain Ridge that the igneous 
assemblages attain major importance. The clay fractions of highly detrital beds, for which the Indus Front has been suggested as a source, have low montmorillonite contents, whereas, the coarse carbonate-rich beds generally have high montmorillonite percentages. The latter, by reflecting the onshore presence of the Decean Traps, indicates that some of the sediment came from areas farther south on the Indian shelf.

Stewart et al. (1965) described the Murray Ridge as a Holocene barrier dividing sedimentation areas. The present study confirms that this ridge and its continuation to the southwest, the Owen Ridge, have been an effective barrier to coarse-grained sedimentation, at least since the Miocene. This is based mainly on differences in coarse fraction mineralogy. Mica and chlorite dominate the sands on the Indus Cone, but to the northwest of the ridge system, quartz and feldspar are usually about equal to or can be more abundant than mica and chlorite. The acid igneous derivatives in the heavy mineralogy of the northwestern sands are considerably more important than on the Cone. Components derived from desert environments are found mainly northwest of the ridges. It is more difficult to find differences between those samples on either side of the ridge system deposited near the time of its tectonic uplift (compare 222-28-5 and 223-19-2).

In Pleistocene stratigraphic sections on both sides of the ridge system, the occurrence of beds containing high percentages of pellets and other shelf fossil debris may indicate a general increase in erosion of shelf sediment over much of the Arabian Sea during periods of low sea level.

In summary, it has been shown by compositional studies that the coarse material of the interbeds originated in, or were carried to shelf areas. The presence of this material in some of the Arabian Sea drill sites suggests transport of mechanisms of sufficient competency to transport coarse sediment over great distances. The presence of only partially abraded carbonate rhombs indicates that these currents or flows were of a density type.

\section{Transport and Sedimentation of the Coarser Grained Material}

Some indications as to mechanisms involved in the deposition of the sand and silt beds can be gained from a consideration of the results of grain-size and sedimentary structure analyses.

\section{Graded Beds}

As already shown in the Presentation of Data section, most of the coarser grained intercalations are graded upwards (Figures 2 and 4). This feature can be considered to indicate that currents carrying particles in suspension have progressively deposited their load according to decreasing particle size with diminishing current energy.

This general model well explains the type of grading which shows a transition to fine sediments at the top of the bed. Sometimes, however, a normally graded unit displays a sharp boundary with the overlying clayey sediment. This could be explained by considering that, occasionally towards the end of the graded sedimentation, the rate of deposition decreases abruptly. In this case, traction transport of the sedimentary particles along the bottom becomes more important, and the graded unit ends abruptly. The occurrence of trough cross lamination at the sharp upper contacts of some such graded units would appear to support this interpretation.

Climbing ripple or ripple drift laminae (Figure 5A) associated with graded beds are interpreted as bed load shifting by currents in conjunction with abundant simultaneous sediment deposition from suspension (Sanders, 1963; McKee, 1966; Jopling and Walker, 1968; Allen, 1970).

Shape analysis of the grain-size curves (Moss, 1962 and Visher, 1969) reveals that the grain-size distribution of most samples taken from graded beds consists of two populations, namely, suspension and saltation. Few samples display all three (traction, saltation, and suspension) populations. Sometimes only the suspension population occurs. On examination of the sets of grain-size curves from the investigated graded beds it appears, for example, that:

1) In graded bed IV, the grain-size distribution of the lowermost sample (F) comprises suspension, saltation, and traction populations; sample (E), taken above it, shows no indication of a traction population; and the remaining samples (D, C, and B), in the upper part of the bed, have a suspension population only (Figure 15);

2) A similar trend can be outlined for graded bed I. Here, though, the traction population was not recorded even in the lower part of the graded sequence (Figure 16).

3) Even when a two-population distribution persists throughout a graded unit, as in graded beds III and VI, the suspension population greatly increases in importance towards the top of the sequence (Figures 17 and 18).

Consequently, it may be argued that the graded units begin with a multiple-population distribution, the particles being transported by suspension, saltation, and possibly traction. This evolves towards a single-population distribution, consisting of suspension-transported particles only. This trend also emerges in the case of the Black Sea abyssal graded beds (Jipa, in press).

These observations indicate the following as a possible mechanism for the graded bedding. At first all the particles were in suspension. Along the transport path of the current, this suspended sedimentary load was redistributed, mainly according to the size of the particles. As the current lost energy and velocity decreased, the sedimentary load began to be deposited, coarse particles first. It is suggested that at this stage the current was strong enough to move a portion of its formerly suspended clastics along the bottom by traction and saltation. In this way, the grain-size distribution of the sediment would encompass more than one population. As velocity decreased further, the current lost its competency to transport bed load by saltation. As well as the decrease in current velocity, this might also be due to the particles at this stage being of smaller size and therefore more difficult to saltate.

At even lower current velocities, the particles originally deposited from suspension would no longer be reworked from the sediment surface, and a single population distribution would result.

The classic turbidity current concept (Kuenen, 1951) holds that graded deep-sea sandy beds are deposited in a 


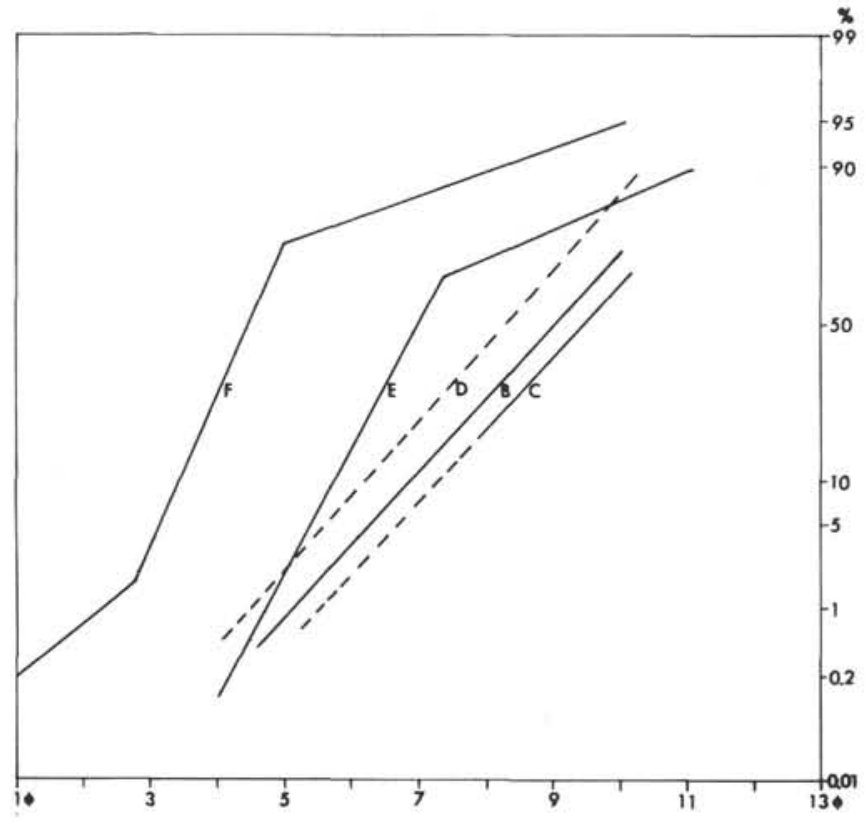

Figure 15. Simplified grain-size curves. Graded bed IV (221-12-2). B to $\mathrm{F}$ indicate the same samples as in Figure 9. Dashed line $=$ uncertain data.

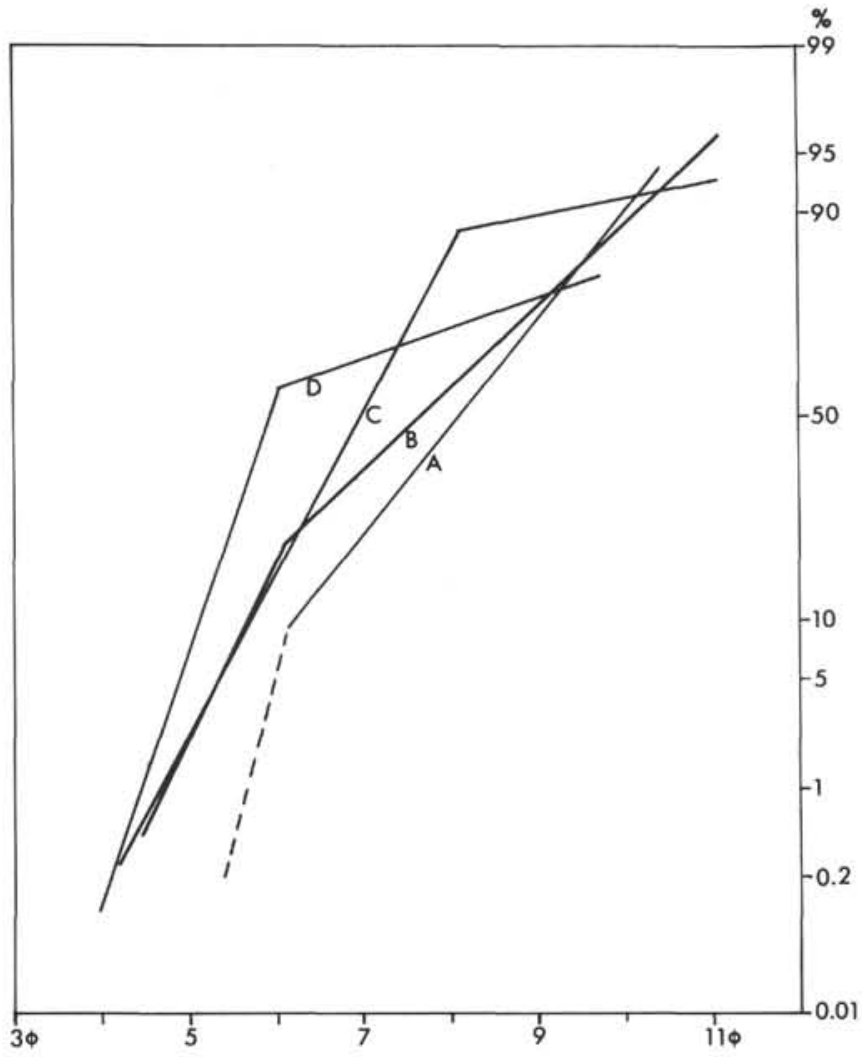

Figure 17. Simplified grain-size curves. Graded bed III (221-10-5). A to D indicate the same samples as in Figure 8. Dashed line $=$ uncertain data .

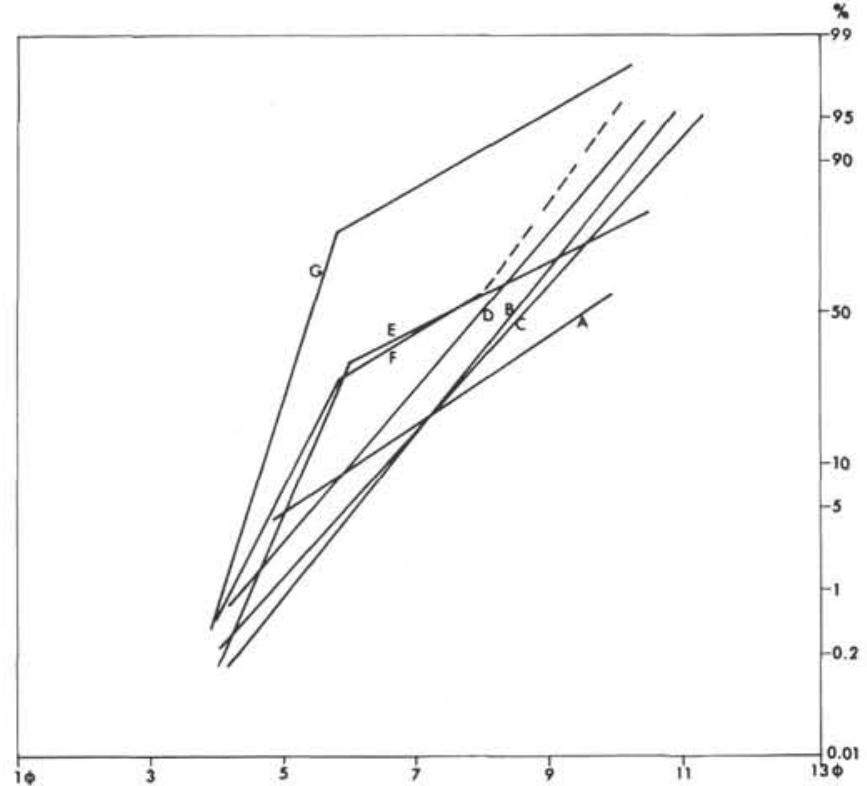

Figure 16. Simplified grain-size curves. Graded bed I (221-5-3 and 4). A to $\mathrm{G}$ indicate the same samples as in Figure 6. Dashed line $=$ uncertain data .

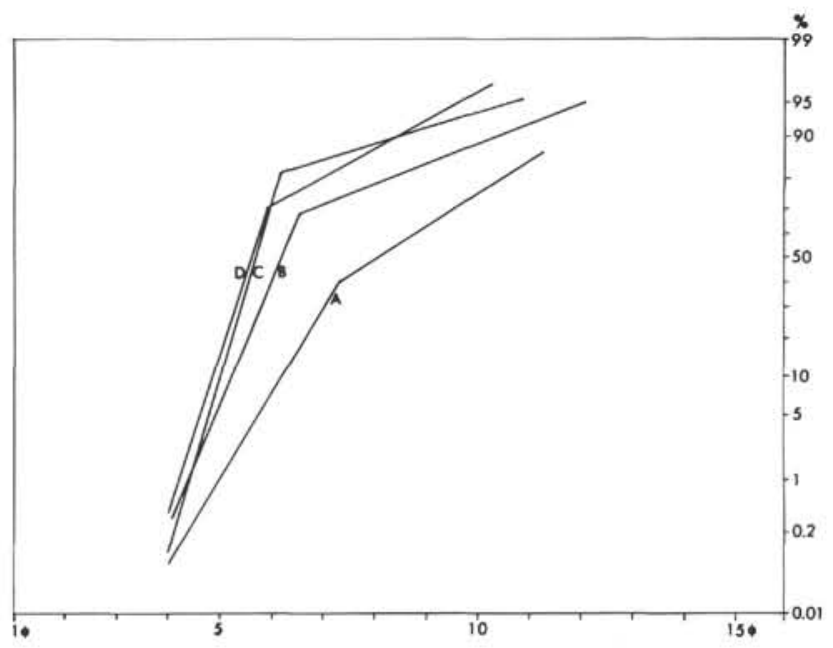

Figure 18. Simplified grain-size curves. Graded bed VI (222-9-3 and 4). A to D indicate the same samples as in Figure 10.

relatively short time interval from spasmodic decelerating relatively high density, high velocity currents. These currents are envisaged as submerged near-bottom, turbulent autosuspension flows, which derive their energy from moving downslope under gravity. It is obvious that such a mechanism would fit very well for most of the graded beds investigated in this study.

Some additional points of interest arise particularly with respect to the other types of grading observed. The multiple grading observed in graded beds II (221-8-2) and IX (224-8-5) can be looked on as a series of superimposed turbidity current interflows following one another rapidly enough to preclude the sedimentation of part of the first's 
suspended load. However, inverted and symmetrical grading cannot be satisfactorily explained in terms of deposition from a single turbidity current.

The absence of the traction grain-size population from most of the analyzed samples might be considered to show that in the areas of Sites 221 and 222, the graded beds were deposited mostly by slow currents. However, the erosional mark observed on the sole of a graded bed (Figure 15), shows that at times faster currents have also been active.

\section{Nongraded Beds}

Grain-size analyses of nongraded bed I, Core 222-28-5 substantiated visual observations that lack of grading does characterize this category of coarser interbeds.

The sand content of the nongraded bed in Core 222-28 is higher than in most graded beds analyzed, and many of the other nongraded beds were visibly coarser than associated graded horizons. This would indicate deposition from very strong currents if all of the sediment was to be originally in suspension. It might be more reasonable here to invoke a normal bottom current mechanism to explain these deposits, transporting its sedimentary material both as bed and suspension load. Supporting this hypothesis is the presence of cross lamination in nongraded beds at Site 222 . In the graded beds climbing and nonclimbing, fore-set lamination occurred more or less truncated at their upper ends (Figure 5E,H). The structural evidence, then, suggests that only a small amount of material settled from suspension while the greater part is shifted along the bottom by currents (Sanders, 1963).

The grain-size parameters of the analyzed nongraded bed, on the other hand, do not show significantly different values from those of the graded beds (Figure 11 and Table 1). This includes the standard deviation values. One would expect geostrophic bottom currents to deposit a cleaner, better sorted sediment. This lack of maturity might be explained by suggesting that former graded bed material was reworked by normal, tractional currents over short distances.

Local reworking, raising clouds of clayey material easily suspended, could also explain the rather large population of suspended grains displayed by nongraded bed I (Figure 19).

A case may be made for the lack of grading and maturity of these beds as being simply apparent features, the result of sampling over a large number of discrete individually graded layers a few grains thick. This concept would entail deposition from tractive bottom currents or "fluidized flowing grain layers" (Sanders, 1965) and involve a large number of individual and independent processes of deposition, erosion, and deposition.

If one accepts such a mechanism for the nongraded beds, it could possibly be applied in a broader sense, to the deposition of the coarse interbeds as a whole. Schiemenz (1960), Hesse (1965), and von Rad (1968) have shown that grain-by-grain deposition from "tractive bottom currents with decreasing or pulsating velocities of ideally sinusoidal trend", could explain recurrent grading in flysch sequences.

A similar hypothesis, assuming longer term depositional periods than are envisaged by the turbidity current theory, might provide a more satisfactory mechanism for anomalous grading in the Indus Cone beds. Symmetrical

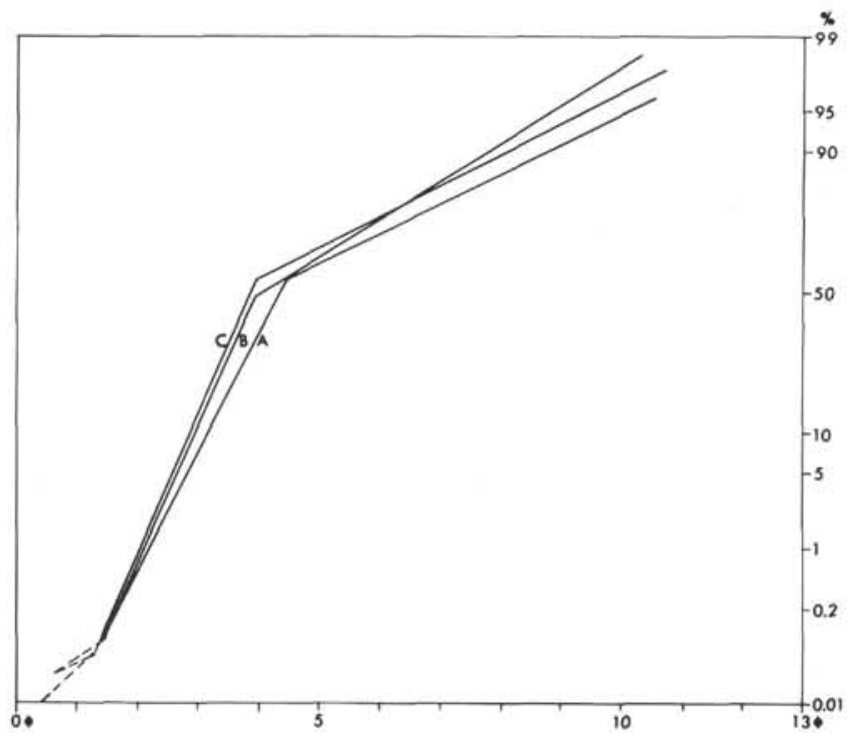

Figure 19. Simplified grain-size curves. Nongraded bed I (222-28-5). A to C indicate the same samples as in Figure 11.

and inverted types, as well as multiple grading and sharp upper contacts on normally graded beds, could be explained by invoking pulses in bottom current velocity. However, the grain-size parameters of the graded beds and their partially abraded carbonate rhombs suggest that most of the coarse material was transported in suspension and, therefore, a turbidity current-type mechanism seems to fit best the sedimentologic evidence.

\section{Individual Laminae}

The sparse available data on individual horizontal laminae, not associated with Indus Cone graded beds, give little indication of their origin.

Isolated laminae might represent a more distal phase of turbidite deposition.

Some laminae, however, are made up of rather clean, well-sorted silty material. One can therefore suppose that, at least in some cases, they are the result of normal bottom current activity carrying the nonindigenous sedimentary material mainly as bed load.

It is also possible that some isolated laminae represent deposition of eolian material brought into the deep-sea environment by dust storms.

\section{Transport and Sedimentation of the Fine-Grained Material}

The deposition of the fine background lithologies of the silt and sand interbeds requires explanation if an indication of the sedimentation processes involved in the development of the Indus Cone is to be gained. At Site 222, two distinct facies are present-the green and gray facies. Apart from the fine-grained lithology found immediately adjacent to the coarse interbeds, the predominant silty clay sediments at Site 221 are similar to those of the green facies at Site 222 .

\section{The Green Facies}

The sediments of greenish coloration are usually made up of nannofossil ooze and detrital components mixed in 
about equal proportions, though the nannofossil fraction can be greater than 50 percent (up to $70 \%$ ).

At Site 222, analyses by the shipboard paleontologists showed that this facies contained only indigenous nannofossils, indigenous planktonic and deep benthonic foraminifera, and a relatively small number of displaced shallow benthonic and reworked Eocene foraminifera. Except for the uppermost interval cored at Site 222, the greenish facies is generally characterized by intense bioturbation.

It is suggested that, compositionally, this facies results from two major sedimentation processes. The predominantly indigenous planktonic fossil content and often high ooze percentages indicate pelagic deposition. On the other hand, the equal importance of detrital components in most smear slides and the presence of some reworked foraminifera indicates that "Hemipelagic" might be a better term.

The uppermost sediments recovered at Site 222, admittedly of a slightly different green facies type, are Pleistocene in age and show no definite bioturbation and higher organic carbon and sand fraction percentages. However, if one considers present-day terrigenous sediment input to the Arabian Sea, as estimated by Goldberg and Griffin (1970), it would appear likely that the detrital fraction outlined above could have been derived mainly from rivers, for example, the Indus, but also partly from eolian dust. This interpretation may be supported by the size distributions (Figure 13), which delineate two populations within the green facies sediments. This influx of terrigenous sediments was probably rather continuous as, even where burrowing was not observed, no primary bedding structures occur.

\section{The Gray Facies}

In sharp contrast to the greenish sediments, the gray facies is almost entirely detrital. Bedding can be conspicuous, especially near intercalated silt and sand beds or laminae. However, long sequences of gray clayey sediments with no visible bedding are found at Site 222 .

The foraminiferal assemblages (see Fleisher, biostratigraphic summary for Site 222, Chapter 6) are no different than those in the green facies. The benthonic foraminifera again indicate a deep-water environment of deposition. The nannofossil assemblages, on the other hand (see Boudreaux, biostratigraphic summary for Site 222, Chapter 6), are mixed. Only a few samples of gray facies sediments contain solely indigenous forms, and this never occurs near coarse interbeds. Reworked Cretaceous to Pliocene nannofossils mixed with indigenous species (Figure 12) indicates probable land derivation while the neritic to upper bathyal benthonic foraminifera suggest the material may have initially accumulated in shelf areas, as did the coarse interbeds.

The gray facies sediments, in comparison to the green, represent a dilution of the truly pelagic biogenous components by an increased supply of detrital material.

The processes involved in the transport of this gray detrital sediment into deep-water areas and deposition there are difficult to determine. A number of possible mechanisms can be put forward:
1) The turbidity current concept, which has been discussed as a mechanism for the deposition of the silt and sand interbeds, is one possibility as the clayey gray sediments obviously represent the background lithology of the coarse beds. This concept maintains that coarse sediments are dispersed along channels on the surface of submarine fans and that fine sediments are dispersed by channel levee overflow into the interchannel areas. Leveed channels are undoubtedly present on the Indus Cone surface but a number of gray facies characteristics do not fit such a hypothesis.

The gray facies sediments show a striking lack of visible bedding structures in those intervals with no sand and silt beds. Also, no typically pelagic intervals with greater biogenous content occur, which should represent quiescent periods between flows. These characteristics seem to reject the possibility of a spasmodic sedimentation agent. The homogeneity of the gray, clayey sediments cannot be explained other than by a long lasting, rather continuous supply of fine-grained material.

2) The well-studied suspended turbid flow mechanism reported in the Santa Barbara Channel, off Southern California, offers another possible mechanism (Drake et al., 1970; Drake 1971; Fleisher, 1972). There a similar alternation of gray and green fine sediment facies occurs. The gray sediments have been related to deposition from turbid flows and associated with periods of major floods. Transmissometer and temperature measurements within the Santa Barbara water column have shown that fine-grained sediment, initially having been rapidly deposited in shelf areas, was resuspended and transported to deep-basin areas in turbid flows. These dense plumes were found to move away from the shelf along marked thermal gradients within the water column and bottom turbid flow in the deep basin was minimal. The transport of gray sediment here, then, was controlled by water stratification, subsurface currents and topography.

In applying this concept to the Arabian Sea, certain favorable conditions are present. Much of the gray clastic material was probably initially deposited on the shelf. Major sediment contributing rivers are susceptible to regular major flood periods. Stirring up and resuspension of shelf sediment is known to occur during the monsoon (down to 400 meters according to Duiing, 1970) and with inshore storm wave effects. The resuspended material may, therefore, leave the neritic zone as low density turbid layers flowing downslope.

In the Santa Barbara Channel, density gradients in the water column prevent the initiation of bottom flow, and the particle suspensions migrate as suspended flows into deep water. In basins with water deeper than 1000 meters, the magnitude of the thermal and salinity gradients is less important (as recorded in the Arabian Sea by the Scripps LUSIAD Expedition: curve 2-83 in Robinson 1966 fig. 2). This could allow both the horizontal and vertical distribution of sedimentary material (Drake, 1971).

Due to lack of published data on bottom conditions in the Arabian Sea, this type of sedimentation remains hypothetical for the Indus Cone. Nevertheless, it is a possible mechanism by which its surface could be provided with a relatively continuous supply of silt and clay-size 
material, and the lithologies that have resulted from its action in the Santa Barbara Channel are undoubtedly similar to those found on the Indus Cone. The influx of clastic material into the water column could be sufficient to greatly dilute the indigenous fossil ooze, being deposited by normal pelagic deposition (together with eolian dust and surface suspensions of terrigenous particles), and produce an almost entirely detrital sediment.

3) The third candidate, as a mechanism for sedimentation of the gray facies sediment, derives its support to some extent from the strengths and inadequacies of the other two hypotheses outlined above. This is the possibility of sedimentation from semipermanent bottom turbid flows: low velocity gravity assisted bottom currents transporting clay and silt particles as low density nepheloid layers close to the sediment surface.

The arguments for the resuspension and subsequent downslope flow of shelf sediment as presented in (2) can be invoked again. However, in the Arabian Sea, in contrast to the Santa Barbara Channel model, the presence of marked temperature/density gradients in the water column has not been documented and no physical measurements have been made on the Indus Cone which would preclude the presence of bottom turbid flows.

The requirement for a fairly continuous major sediment supply to the depositional surface, which was the main problem with the turbidity current hypothesis, could be met by this mechanism. The lack of visible lamination or bedding in the sediment does not preclude deposition from low velocity currents. (X-radiographs of Tyrrhenian Sea cores show fine lamination and other current structures in similar fine visually homogeneous sequences (Kidd, in preparation) and magnetic fabric studies confirm the presence of low velocity currents (Frederick 1972)).

The third mechanism would provide a more plausible explanation for the characteristics of the green to gray facies contacts. These are sharp lithological breaks and appear unlikely to have resulted from a change to a similar process of essentially pelagic-type fractionation of particles through a few thousand meters of water column (as in mechanism 2).

Attempts were made to roughly estimate from Stokes' Law, the relative sedimentation rates of the gray and green facies sediments, assuming both accumulated by essentially pelagic deposition (i.e., the suspended flow mechanism for gray facies). Even if the suspended flows were entering the water column as deep as 1000 meters, their detrital material $(\mathrm{Md}=3 \mu)$ would take slightly longer to reach the sea floor $(3546 \mathrm{~m}$ at Site 222$)$ than green facies type material $(\mathrm{Md}=$ $4 \mu$ ) from the surface and photic zone. This would not seem to fit with the observed rapid facies changes.

Also, at these contacts, there is an abrupt termination of the burrowing activity which is characteristic of the greenish facies. This is most likely to have resulted from some rapid change in biological environment at the sediment-bottom water interface.

\section{Development of the Indus Cone}

The Himalayan area became dry land at the end of the Eocene and developed a major river system at the beginning of the Siwalik epoch (Middle Miocene)(Gansser, 1964). This river had the Assam Brahmaputra as its headwaters (named the Indobrahm by Pascoe, 1920) but was reduced by fluival capture to the size of the present Indus. The continuous supply of sediment to the Arabian Sea by this river from Middle Miocene to Recent times has been mainly responsible for the building of an impressively large submarine fan.

It has been shown in this study that much of the Indus Cone sediment was initially deposited on the western India continental shelf. However, when the range of possible transport and deposition mechanisms for both the silt and sand interbeds and their dominant background lithologies is considered, an overall picture of the sedimentary history of the Cone is less clear.

Pelagic sedimentation was probably taking place continuously during the development of the Indus Cone, but during deposition of the gray facies, pelagic components were highly diluted by the huge terrigenous sediment contribution. Even during bloom periods, it would be difficult for the biogenous ooze component to surpass this input rate.

The larger amounts of pelagic material in the greenish facies of Site 222 could have accumulated during temporary restrictions in Indus River sediment supply (possibly related to Himalayan tectonic events) or during periods of differing climatic and/or physical conditions which restricted the major processes of clastic deposition. A further possibility is a shift in locus of the gray facies sedimentation. The very high overall sedimentation rate encountered at the Indus Cone drill sites (for example, greater than $200 \mathrm{~m} / \mathrm{m} . \mathrm{y}$. at Site 222) probably represents an even faster rate of gray facies deposition interspersed with relatively slow deposition, at hemi-pelagic rates, in the green facies periods.

The classic theory of spasmodic deposition from turbidity currents cannot possibly account for all of the features displayed in the cores. Relatively continuous deposition from turbid flows would appear to be the major process involved in the sedimentation of the gray facies sediments.

One possible overall picture envisages a relatively continuous "rain" of fine-grained terrigenous particles from suspended turbid flows interrupted by spasmodic deposition of silt and fine sand by turbidity currents. The coarse interbed material would be mostly drawn from around the Indus delta front by slumping into the Swatch Submarine Canyon and, thereby, be transported by turbidity currents by way of leveed channels on the Cone surface. Other turbidity currents, originating in shelf areas farther south and on the Laccadive-Maldive Ridge, would supply highly biogenous coarse material. The dominant sedimentation mechanism, though, would be grain-by-grain deposition from turbid flows of resuspended shelf material moving along thermal or salinity density gradients in the water column. Wind blown particles from dust storms and very fine material carried by surface currents would add to this "rain" of sediment.

The sharp contacts between the green and the gray muds at Site 222, and the abrupt termination of burrowing activity at these boundaries, argue to some extent for the turbid flows to be bottom-seeking instead of intermediate 
level flows. This modification of the overall picture would therefore envisage bottom turbid flows with spasmodic turbidity current deposition accounting for most of the terrigenous detritus.

Both of these concepts raise the question of where in the fine lithology does one divide between the top of a turbidity current deposit and the succeeding turbid flow deposition. No apparent differences in grain size, primary structures, or composition help with this.

Both concepts also require explanation of the anomalous structural and textural features of some of the interbeds. These might be explained in terms of turbidity current deposited graded beds being reworked on the surface of the Cone by contour currents. The anomalous beds show some of the features believed to be typical of "contourites" with the notable exception of good sorting (Bouma, 1972). It should be noted, however, that the silling effect of the Carlsberg and Chagos-Laccadive ridges would appear to preclude the activity of major geotrophic currents at these depths. Tractive reworking by the envisaged fine sediment bottom turbid flows is a more feasible possibility. In the absence of bottom current measurements on the Indus Cone, these suggestions are, however, merely speculative.

A further possibility, as an overall process in the development of this submarine fan, is an extension of the ideas put forward in the discussion of an alternative mechanism to turbidity currents for the anomalously structured interbeds. The concept of less spasmodic deposition of coarse-grained material from tractive bottom currents with decreasing or pulsating velocities already envisages an environment under the influence of semipermanent bottom turbid flows of finer material(von Rad, 1968). This suggestion appeals in its overall treatment of the sedimentation processes but fails to explain the evidence of sand-size graded bed material having been transported primarily in suspension.

\section{CONCLUSIONS}

It has been recognized that spasmodic deposition from individual turbidity current flows is insufficient, on its own, to account for the lithological successions encountered at Sites 222 and 221. A number of other possibilities can be put forward to account for the huge sedimentary pile comprising the Indus Cone.

Turbid flows of fine-grained material, either as bottom-following nepheloid layers or as suspended flows following thermal or salinity gradients in the water column, are regarded as the major depositional process. Spasmodic turbidity current type activity combined with these could account for the intermittent deposition of coarser grained interbeds. The evidence of more normal bottom current activity seems to most readily fit an overall sedimentation process involving semipermanent bottom turbid flows and spasmodic turbidity current events.

In order to progress beyond the various ideas outlined in this paper, it is obvious that more data on physical conditions are needed. Information from sea floor current and photographic studies, nephelometer measurements, and eolian dust sampling over future years could answer many of the questions posed here. It is also suggested that any future drilling in the area or further work on the recovered
Leg 23 cores, should incorporate X-radiograph (and possibly magnetic fabric) studies together with sampling in even greater detail than was possible here, for carbon carbonate, paleontological, and X-ray mineralogical studies.

\section{REFERENCES}

Allen, J. R. L., 1970. A quantitative model of climbing ripples and their cross-laminated deposits: Sedimentology, v. 14 , p. 5-26.

Aston, S. R., Chester, R., Johnson, L. R., and Padgham, R. C., 1973. Aeolian dust from the lower atmosphere of the eastern Atlantic and Indian oceans, China Sea and Sea of Japan: Marine Geol., v. 14, p. 15-28.

Beiersdorf, H., 1972. Schwermineraluntersuchungen an Sedimenten aus West Pakistan sowie vom angrenzenden Schelf. "Meteor" Forsch.-Ergebnisse, Reihe C., BerlinStuttgart.

Bouma, A. H., 1972. Recent and ancient contourites: Gulf Coast Assoc. Geol. Soc. Trans. v. 22, p. 205-232.

Drake, D. E., 1971. Suspended sediment and thermal stratification in Santa Barbara Channel, California: Deep-Sea Res., v. 18, p. 763-769.

Drake, D. E., Fleischer, P., Kolpack, P. L., 1970. Transport and deposition of flood sediment, Santa Barbara Basin, California (abs.): Am Geophys. Union Trans., v. 51, p. 767.

Düing, W., 1970. The monsoon regime of the currents in the Indian Ocean: Honolulu, (East-West Cent. Press), p. 68.

Fleischer, P., 1972. Mineralogy and sedimentation history, Santa Barbara Basin, California: J. Sediment. Petrol., v. 42 , No. 1 , p. $49-58$.

Frederick, D., 1972. The magnetic fabric of some Recent marine sediments: Ph.D. Thesis, Univ. Southampton.

Folk, R. L. and Ward, W. C., 1957. Brazos River bar: a study in the significance of grain size parameters: J. Sediment. Petrol., v. 31, p. 514-529.

Gansser, A., 1964. Geology of the Himalayas: Zurich (Interscience, 289 pages).

Goldberg, E. D. and Griffin, J. J., 1970. The sediments of the northern Indian Ocean: Deep-Sea Res., v. 17, p. 513-537.

Hesse, R., 1965. Herkunft und Transport der Sedimente im Bayerischen Flyschtrog: Z. Deutsh. Geol. Ges., v. 116, p. 403-426.

Jipa, D. C., in press. Graded bedding in some recent Black Sea turbidites: a textural approach, Black Sea Volume: Woods Hole, Mass. (Woods Hole Oceanographic Institution).

Jopling, A. V. and Walker, R. G., 1968. Morphology and origin of ripple-drift cross-lamination, with examples from the Pleistocene of Massachusetts: J. Sediment. Petrol., v. 38, p. 971-984.

Kidd, R. B., in preparation. Doctoral Thesis.

Krumbein, W. C. and Pettijohn, F. J., 1938. Manual of sedimentary petrography: New York (AppletonCentury-Crofts), $549 \mathrm{p}$.

Kuenen, Ph. H., 1951. Properties of turbidity currents of high density. In Turbidity currents and the transportation of coarse sediments to deep water: Soc. Econ. Paleont. Min., Spec. Publ. 2, p. 14-33.

McKee, E. D., 1966. Significance of climbing-ripple structure: U.S. Geol. Surv., Prof. Papers 550-D, p. D94-D103. 
Moss, A. J., 1962. The physical nature of common sandy and pebbly deposits, Part II: Am. J. Sci., v. 261, p. 297-343.

Pascoe, E. H., 1920. The early history of the Indus, Brahmaputra and Ganges: Quart. J. Geol. Soc. London, v. 75, p. $135-138$.

Passega, R., 1964. Grain size representation by CM patterns as a geological tool: J. Sediment. Petrol., v. 34, p. 830-847.

von Rad, U., 1968. Comparison of sedimentation in the Bavarian Flysch (Cretaceous) and Recent San Diego Trough (California): J. Sediment. Petrol., v. 38 No. 4, p. 1120-1154.

Robinson, M. K., 1966. Arabian Sea. In Fairbridge, R. W., The Encyclopedia of Oceanography: New York (Van Nostrand Reinhold Co.), p. 40-43.

Sanders, J. E., 1963. Concepts of fluid mechanics provided by primary sedimentary structures: J. Sediment. Petrol., v. 33 , p. $173-179$.

1965. Primary sedimentary structures formed by turbidity currents and related resedimentation mechanisms. In Middleton, G. V. (Ed.), Primary sedimentary structures and their hydrodynamic interpretation: Soc. Econ Paleont. Min. Spec. Publ. No. 12, p. 192-219.

Sarnthien, M., 1971. Oberflachensedimente im Persischen Golf und Golf von Oman, II. Quantitative Kormponentenanalyse der Grobfraction: "Meteor" Forsch.Ergebnisse Reihe E., 5, Berlin-Stuttgart p. 1-113.

Schiemenz, S., 1960. Fazies und Palaogeographie der Subalipiner Molasse Zwischen Bodensee und Isar: Geol Jahrb., Beihefte, v. 38, 119 p.

Schott, W., Stackelberg, U.von, Eckardt, F. J., Mattiat, B., Peters, J., and Zobel, B., 1970. Geologische Untersuchungen an Sedimenten des indischpakistanischen Kontinentalrandes (Arabisches Meer): Geol. Rundschau., v. $60,(\mathrm{I})$, p. $264-275$.

Stackleberg, U. von, 1972. Faziesverteilung in Sedimenten des Indisch-Pakistanischen Kontinentalrandes (Arabisches Meer) "Meteor" Forsch.-Engebnisse Reihe C No. 9 p. 1-73. Berlin-Stuttgart.

Stewart, R. A., Pilkey, O. H., and Nelson, B. W., 1965. Sediments of the northern Arabian Sea: Mar. Geol. v. 3, p. 411-417.

Visher, G. S., 1969. Grain size distribution and depositional processes: J. Sediment. Petrol., v. 39, p. 1074-1106.

APPENDIX A

\section{DETAILED DESCRIPTION OF INDIVIDUAL BEDS}

\section{Graded Beds}

\section{Graded Bed I (221-5-4, $47 \mathrm{~cm}-221-5-3,126 \mathrm{~cm})$}

This Upper Pleistocene bed consists of $71 \mathrm{~cm}$ of gray silt becoming a darker gray and clayey near the top. Grain-size analysis reveals a decrease of the silt fraction from over 90 percent at the base to about 25 percent in the upper part of the bed (Figure 6I). The decrease is systematic in the lower part but less regular within the rest of the bed.

Median (Md) and mean (Mz) values decrease upward from over 16 microns to approximately 2 microns. The grain-size values corresponding to the coarsest 1 percent on the cumulative curve (C index according to Passega, 1964) decrease slightly between 60 microns and 25 microns (Figure 6II).

The standard deviation $(=1.4$ to 2.6$)$, skewness $\left(\mathrm{SK}_{1}=-0.1\right.$ to $0.6)$, and kurtosis $\left(\mathrm{K}_{\mathrm{G}}=0.3\right.$ to 1.1$)$ values when plotted vertically through the bed describe irregular curves. They apparently are not influenced by the grading (Figure 6III; Table 10).

All samples contain between 0.1 and 0.5 percent sand grains except the uppermost sample, which contains 4.7 percent sand. This abnormal value does not change the general trends, except in the case of the $\mathrm{C}$ index and the C/Md diagram. With the exception of this topmost control point, the simultaneous variations of $\mathrm{C}$ and $\mathrm{Md}$ describe a rather continuous, slightly inclined curve (Figure 6IV).

The sand fraction from two samples collected at the base of the graded bed $(221-5-4,40-42 \mathrm{~cm}$ and $46-47 \mathrm{~cm})$ has been analyzed for composition (Tables 1 and 5). The detrital component is mica dominated. The category for "other biogenous" material comprises mostly fecal pellets and is an important part of this count. The benthonic foraminifera, according to R. Fleisher, lived in depths less than those suggested by the background lithology, as did the ostracods, thick mollusc fragments, and plant debris. Apart from the micas, heavy minerals are confined to the lowermost sample. The presence of partly rounded carbonate clasts suggests suspended current transport. The heavy mineral count shows an abundance of metamorphic-type minerals, which concurs with the observed texture of the quartz grains. There is also some influence of an acid igneous source in the form of brown hornblende and alkali feldspar. The smear slides show that the $40-42 \mathrm{~cm}$ level contains more nannofossil material than that at $46-47 \mathrm{~cm}$. The fecal pellets grade upward in size and number, and the gradation is mainly within the silt range. The carbon-carbonate data from this bed show a $\mathrm{CaCO}_{3}$ level of between 58 and 64 percent. The bulk X-ray sample taken at $30-35 \mathrm{~cm}$ contains 63 percent aragonite, suggesting that the pellets are aragonitic.

This graded bed is stratigraphically the lowest of three noted in this core. The other two have a higher detrital content. This unit is distinctive for its fecal pellet content and their size grading.

\section{Graded Bed II (221-8-2, 15-86 cm)}

This is a lower Pleistocene greenish-gray sequence resting with a sharp base on yellow green silt. In the shipboard examination, it was suspected that the boundary between its silty and clayey parts (i.e., near $52 \mathrm{~cm}$ ) might represent a rapid transition.

The graded bed has suffered flowage due to drilling disturbance. The grain-size distribution of eight samples taken in this graded sequence is shown (Table 10). The sand content gradually decreases from about 9 percent at the base to less than one percent near the middle (Figure 7I). The silt content also presents a generally decreasing trend (from 72 percent silt at the base to around 21 percent silt at the top). However, an important jump in silt content occurs in the upper part of the silty interval. The amplitude of this jump is most striking within the silt fraction, and marked decreases occur at the same level in the sand and clay fractions (Figure 7I).

The same diminishing trend is shown by the values of the median, mean, C index, standard deviation, skewness, and kurtosis (Figures 7II and III). The sudden increase in silt content coincides with similar increases in these parameters and the C/Md curve is broken at the same level (Figure 7IV).

The composition of two samples, one from the very bottom of the bed at $83-85 \mathrm{~cm}$ and the other at $57-60 \mathrm{~cm}$, has been investigated (Tables 1 and 5).

The sand fractions are dominated by micas, with green varieties being most prominent. In the $57-60 \mathrm{~cm}$ sample, the remaining material is mostly plant debris and shell fragments, whereas, the $83-85 \mathrm{~cm}$ sample has a more prominent quartz, feldspar, and heavy mineral content. Benthonic foraminifera in the latter sample are believed to have originated in shallower water areas (according to R. Fleisher), and the plant remains would seem to confirm this. Analysis of the heavy mineral separation shows a dominance of abraded carbonate rhombs. This suggests a current mode of transport mostly in suspension as this is a mineral of low resistance to erosion in transport.

Garnet, kyanite, actinolite, and green hornblende are most prominent in the heavy mineral count. The major source is interpreted as being a metamorphic terrain with a secondary influence of an acid igneous source indicated by brown hornblende and microcline grains.

Smear slide examination shows only a trace of nannofossils. Rare broken discoasters occur, indicating reworking of pre-Pleistocene sediments. Carbon carbonate analyses show that carbonate varies inversely with grain size; from 45 percent at the $57-60 \mathrm{~cm}$ level to less than 25 percent in the basal sample. Petrographic study reveals that mica still dominates the silt fraction and that the remaining 
TABLE 10

Grain-Size Analysis of Graded and Nongraded Beds, Sites 221 and 222

\begin{tabular}{|c|c|c|c|c|c|c|c|c|c|c|}
\hline \multicolumn{2}{|c|}{ Samples } & \multicolumn{3}{|c|}{ Grain-Size Fractions } & \multirow[b]{2}{*}{$\operatorname{Md}_{(\phi)}$} & \multirow[b]{2}{*}{$\mathrm{Mz}_{(\phi)}$} & \multirow[b]{2}{*}{$\sigma_{1}$} & \multirow[b]{2}{*}{$\mathrm{Sk}_{\mathrm{I}}$} & \multirow[b]{2}{*}{$K_{\mathrm{G}}$} & \multirow[b]{2}{*}{$\mathrm{C}_{(\phi)}$} \\
\hline $\begin{array}{l}\text { Site, Core } \\
\text { Section }\end{array}$ & $\begin{array}{l}\text { Interval } \\
(\mathrm{cm})\end{array}$ & $\begin{array}{c}\text { Sand } \\
(\%)\end{array}$ & \begin{tabular}{l|} 
Silt \\
$(\%)$
\end{tabular} & $\begin{array}{l}\text { Clay } \\
(\%)\end{array}$ & & & & & & \\
\hline \multicolumn{2}{|c|}{ Graded Bed I } & & & & & & & & & \\
\hline $221-5-3$ & $\begin{array}{l}128-129 \\
133-134 \\
137-138 \\
147-148\end{array}$ & $\begin{array}{l}4.7 \\
0.1 \\
0.2 \\
0.4\end{array}$ & $\begin{array}{l}24.9 \\
35.4 \\
30.2 \\
49.7\end{array}$ & $\begin{array}{l}70.4 \\
64.5 \\
69.6 \\
49.9\end{array}$ & $\begin{array}{l}9.5 \\
8.3 \\
8.8 \\
8.0\end{array}$ & $\begin{array}{l}9.5 \\
8.4 \\
8.6 \\
7.9\end{array}$ & $\begin{array}{l}2.6 \\
1.4 \\
1.6 \\
1.6\end{array}$ & $\begin{array}{r}0.0 \\
0.0 \\
-0.1 \\
0.0\end{array}$ & $\begin{array}{l}0.9 \\
1.1 \\
1.0 \\
1.0\end{array}$ & $\begin{array}{l}1.7 \\
5.2 \\
4.9 \\
4.4\end{array}$ \\
\hline $221-5-4$ & $\begin{array}{l}18-20 \\
35-37 \\
42-44\end{array}$ & $\begin{array}{l}0.2 \\
0.0 \\
0.5\end{array}$ & $\begin{array}{l}55.8 \\
56.9 \\
91.1\end{array}$ & $\begin{array}{r}44.0 \\
43.1 \\
8.3\end{array}$ & $\begin{array}{l}7.4 \\
7.6 \\
5.7\end{array}$ & $\begin{array}{l}8.0 \\
7.3 \\
6.0\end{array}$ & $\begin{array}{l}2.6 \\
1.6 \\
1.4\end{array}$ & $\begin{array}{l}0.6 \\
0.1 \\
0.4\end{array}$ & $\begin{array}{l}0.3 \\
0.8 \\
0.7\end{array}$ & $\begin{array}{l}4.5 \\
4.4 \\
4.1\end{array}$ \\
\hline \multicolumn{11}{|c|}{ Graded Bed II } \\
\hline $221-8-2$ & $\begin{array}{l}32-33 \\
47-48 \\
56-57 \\
61-62 \\
64-65 \\
73-74 \\
84-85\end{array}$ & $\begin{array}{l}0.0 \\
0.1 \\
1.0 \\
0.2 \\
1.5 \\
3.7 \\
9.1\end{array}$ & $\begin{array}{l}21.3 \\
34.6 \\
66.5 \\
56.4 \\
70.1 \\
69.7 \\
72.0\end{array}$ & $\begin{array}{l}78.7 \\
65.3 \\
32.6 \\
43.4 \\
28.4 \\
26.6 \\
18.9\end{array}$ & $\begin{array}{l}9.7 \\
8.8 \\
7.3 \\
7.9 \\
7.0 \\
6.7 \\
5.8\end{array}$ & $\begin{array}{l}9.7 \\
9.4 \\
7.9 \\
8.6 \\
7.6 \\
7.2 \\
6.2\end{array}$ & $\begin{array}{l}1.7 \\
2.3 \\
2.0 \\
1.9 \\
2.4 \\
2.3 \\
2.5\end{array}$ & $\begin{array}{l}0.1 \\
0.5 \\
0.4 \\
0.6 \\
0.4 \\
0.4 \\
0.4\end{array}$ & $\begin{array}{l}0.8 \\
0.9 \\
1.7 \\
1.2 \\
1.3 \\
1.4 \\
1.2\end{array}$ & $\begin{array}{l}5.2 \\
5.7 \\
4.0 \\
5.0 \\
3.4 \\
3.2 \\
2.6\end{array}$ \\
\hline \multicolumn{11}{|c|}{ Graded Bed III } \\
\hline $221-10-5$ & $\begin{array}{c}90-91 \\
102-103 \\
139-140 \\
149-150\end{array}$ & $\begin{array}{l}0.2 \\
0.0 \\
0.1 \\
0.0\end{array}$ & $\begin{array}{l}44.8 \\
54.2 \\
82.3 \\
70.1\end{array}$ & $\begin{array}{l}55.1 \\
45.8 \\
17.6 \\
29.9\end{array}$ & $\begin{array}{l}8.2 \\
7.2 \\
7.1 \\
6.4\end{array}$ & $\begin{array}{l}8.1 \\
7.6 \\
7.1 \\
7.4\end{array}$ & $\begin{array}{l}1.5 \\
1.7 \\
1.6 \\
2.5\end{array}$ & $\begin{array}{r}-0.5 \\
0.3 \\
0.2 \\
0.6\end{array}$ & $\begin{array}{l}0.9 \\
0.8 \\
2.2 \\
1.1\end{array}$ & $\begin{array}{l}5.7 \\
4.8 \\
4.7 \\
4.5\end{array}$ \\
\hline \multicolumn{11}{|c|}{ Graded Bed IV } \\
\hline $221-12-2$ & $\begin{array}{c}3-4 \\
17-18 \\
32.5-33.5 \\
43-44 \\
51-52 \\
58-59\end{array}$ & $\begin{array}{r}0.2 \\
0.0 \\
0.2 \\
0.3 \\
0.2 \\
23.4\end{array}$ & $\begin{array}{l}39.8 \\
30.5 \\
17.2 \\
48.8 \\
69.4 \\
65.4\end{array}$ & $\begin{array}{l}60.0 \\
69.5 \\
82.6 \\
50.9 \\
30.4 \\
11.2\end{array}$ & $\begin{array}{l}8.6 \\
9.0 \\
9.4 \\
8.1 \\
7.0 \\
4.4\end{array}$ & $\begin{array}{l}8.9 \\
9.0 \\
9.5 \\
8.2 \\
7.7 \\
5.0\end{array}$ & $\begin{array}{l}2.1 \\
1.6 \\
1.6 \\
1.4 \\
2.0 \\
1.8\end{array}$ & $\begin{array}{l}0.2 \\
0.0 \\
0.1 \\
0.1 \\
0.6 \\
0.6\end{array}$ & $\begin{array}{l}0.9 \\
0.9 \\
0.9 \\
0.7 \\
1.2 \\
1.9\end{array}$ & $\begin{array}{l}4.9 \\
5.2 \\
5.2 \\
4.4 \\
4.7 \\
2.3\end{array}$ \\
\hline \multicolumn{11}{|c|}{ Graded Bed VI } \\
\hline $222-9-3$ & $\begin{array}{c}81-83 \\
94-96 \\
113-115 \\
135-137\end{array}$ & $\begin{array}{l}0.0 \\
0.5 \\
0.3 \\
0.1\end{array}$ & $\begin{array}{l}43.3 \\
68.0 \\
77.6 \\
88.3\end{array}$ & $\begin{array}{l}56.7 \\
31.5 \\
22.1 \\
11.6\end{array}$ & $\begin{array}{l}8.3 \\
6.9 \\
6.4 \\
5.8\end{array}$ & $\begin{array}{l}8.6 \\
7.6 \\
7.0 \\
6.1\end{array}$ & $\begin{array}{l}2.1 \\
2.1 \\
1.9 \\
1.4\end{array}$ & $\begin{array}{l}0.1 \\
0.5 \\
0.6 \\
0.7\end{array}$ & $\begin{array}{l}0.9 \\
1.1 \\
1.4 \\
1.9\end{array}$ & $\begin{array}{l}5.2 \\
4.3 \\
4.4 \\
4.4\end{array}$ \\
\hline $222-9-4$ & $\begin{array}{c}5-7 \\
32.5-34.5\end{array}$ & $\begin{array}{l}0.6 \\
0.9\end{array}$ & $\begin{array}{l}86.5 \\
91.5\end{array}$ & $\begin{array}{r}12.9 \\
7.6\end{array}$ & $\begin{array}{l}5.6 \\
5.2\end{array}$ & $\begin{array}{l}6.1 \\
5: 4\end{array}$ & $\begin{array}{l}1.4 \\
1.2\end{array}$ & $\begin{array}{l}0.6 \\
0.5\end{array}$ & $\begin{array}{l}0.9 \\
1.7\end{array}$ & $\begin{array}{l}4.2 \\
4.0\end{array}$ \\
\hline \multicolumn{11}{|c|}{ Nongraded Bed } \\
\hline $222-28-5$ & $\begin{array}{l}74-75.5 \\
84-86 \\
93-94.5\end{array}$ & $\begin{array}{l}22.9 \\
26.6 \\
26.6\end{array}$ & $\begin{array}{l}63.8 \\
63.2 \\
63.2\end{array}$ & $\begin{array}{l}13.3 \\
10.2 \\
10.2\end{array}$ & $\begin{array}{l}5.3 \\
5.0 \\
5.1\end{array}$ & $\begin{array}{l}5.5 \\
5.1 \\
5.2\end{array}$ & $\begin{array}{l}2.0 \\
1.9 \\
2.0\end{array}$ & $\begin{array}{l}0.2 \\
0.1 \\
0.2\end{array}$ & $\begin{array}{l}1.2 \\
1.2 \\
1.2\end{array}$ & $\begin{array}{l}2.3 \\
2.0 \\
2.0\end{array}$ \\
\hline
\end{tabular}

sediment is almost wholly detrital containing quartz, plagioclase feldspar, calcite rhombs and fragments, and heavy minerals. Total carbonate drops to 13 percent. There, no aragonite was recorded, and the X-ray bulk mineralogy results show a dominance of mica and chlorite grains. Core 8 has another graded horizon in Section 1, while Sections 4 and 5 contain only disturbed coarse silts. Section 3 was void, and it is suspected that the drilling has been restricted by the coarser parts of other silt and sand units. All of the smear slides taken from this core contain only traces of nannofossils except that taken from a thin interval at $221-2-110 \mathrm{~cm}$, which contains 85 percent nannofossils. It lays directly below the graded sequence discussed here. A possible explanation for this thin fossiliferous interval is that deposition was in pulses following one another rapidly enough to allow only the deposition of thin beds of the background lithology at the very tops of the graded intervals.

\section{Graded Bed III (221-10-6, $8 \mathrm{~cm}-221-10-5,90 \mathrm{~cm})$}

This is a lower Pleistocene fine-grained, olive-colored sequence with a sharp base, gradually passing upwards into silty clays.

Grain-size analysis (Table 10) reveals an increase in silt content near the base, from 70 to 82 percent silt, followed by a marked decrease to less than 50 percent silt. Figure $8 \mathrm{I}$ indicates that this change in silt content occurs mostly in the finer grained part of the silt fraction. Particles coarser than 30 microns and finer than one micron show a different behavior.

The grain-size parameters, $\mathrm{Md}, \mathrm{Mz}, \sigma_{\mathrm{I}}$ and $\mathrm{Sk}_{\mathrm{I}}$ show significant variation only at the base and top of the sampled interval. Kurtosis seems to be most affected by the increase in silt content near the base of the bed (Figures $8 \mathrm{II}$ and III).

On the C/Md diagram, a continuous curve is delineated (Figure 8IV). Two samples were collected for compositional analy sis at the 
bottom of the bed: $221-10-6,1-3 \mathrm{~cm}$ and $6-8 \mathrm{~cm}$. Only small amounts of sand were recovered by the wet sieving of these two samples so that only the $1-3 \mathrm{~cm}$ sand sample were studied petrographically (Table 1). Apart from small amounts of mica and quartz, this fraction is entirely biogenous, comprising mostly shell fragments and globigerinid tests together with minor amounts of spicules, radiolarians, pteropods, and ostracods. Much of this shell material contains pyrite infilling and is probably of outer shelf derivation (cf. Schott et al., 1970). Nonindigenous benthonic foraminifera also occur.

The smear slide and X-ray data supply some important information on this bed. Nannofossil content is only 10 percent in both samples, but calcareous material completely dominates the sediment. In particular, pellets make up over a third of the sediment, and carbonate needles are next in importance. Both seem, from X-ray data, to be aragonitic. Clastic material, for example, mica, quartz, and calcite, makes up less than 10 percent of the total, and micarb constitutes a similar amount. Discoasters are again fairly prominent in the nannofossil fraction and indicate reworking of pre-Pleistocene sediments.

The light-colored sediments of Core 10 generally have a higher nannofossil content than the unit described above.

In Core 10, only one other graded horizon occurs, a badly disturbed unit in Section 3, which displays a higher percentage of detrital material. However, a number of carbonate clastic-rich laminae are present in this core, and a source or sedimentation history differing from that of the beds with a higher detrital content may be indicated.

\section{Graded Bed IV (221-12-2, 63-3 cm)}

This is a dark Pliocene bed resting with a sharp base on light gray homogeneous clay. The bed is intercalated in a background lithology of gray calcareous detrital clay and silt.

The content of sand and silt decreases continually from the base (23 percent sand and 65 percent silt) to the middle of the bed $(32-33 \mathrm{~cm} ; 0.2$ percent sand and 17 percent silt). The silt content then increases again, reaching 40 percent at the top of the bed. The same reversal in trend is also indicated by the $\mathrm{Md}, \mathrm{Mz}, \mathrm{C}, \sigma_{\mathrm{I}} \mathrm{Sk}_{\mathrm{I}}$ and $\mathrm{K}_{\mathrm{G}}$ values which show a marked decrease in the lower part of the bed followed by a slight reversal, corresponding to the upper clayey part (Figure 9; and Table 10).

On the $\mathrm{C} / \mathrm{Md}$ diagram, this general trend leads to a curve consisting of two almost parallel segments evolving in opposite directions (Figure 9IV).

The sand fraction composition of two basal samples (221-12-2, $61-63 \mathrm{~cm}$ and $53-55 \mathrm{~cm}$ ) was studied. Plant debris and green micas completely dominate the sand fractions of these two specimens, particularly in the sand at $53-55 \mathrm{~cm}$ where plant fibers and micas make up all but 5 percent of the fraction. Micas are again most prominent in the other sand at $61-63 \mathrm{~cm}$; fibers are of lesser importance and the quartz, feldspar, and heavy mineral percentages are increased. The quartz grains are angular while the smaller heavy minerals are rounded, indicating that the latter are second-cycle. Sand-size carbonate fragments again occur.

The heavy mineral count of the $61-63 \mathrm{~cm}$ separation indicates a dual source, although only a few grains were counted. Garnet, actinolite, and green hornblende from a metamorphic terrain are present and monazite and alkali feldspar are of acid igneous origin.

Smear slides from the unit show only a trace of nannofossils debris, and the micarb content is low. The plant remains are seen to be confined to the sand ranges except in the $61-63 \mathrm{~cm}$ sample, and there a high percentage of detrital material occurs. The bulk X-ray mineralogy confirms the high clastic component as one which is mica and chlorite dominated, with quartz next in importance. Carbonate values here are less than 15 percent, which agrees with the carbon carbonate data. No aragonite was noted in this bed.

\section{Graded Bed V (222-6-4, 140-100 cm)}

This sequence occurs within an Upper Pliocene light gray clayey sediment, showing a sharp base and obvious grading.

Results of four samples analyzed by the DSDP shorelaboratory (Table 6) indicate grading from a silt at the bottom to a silty clay at the top of the bed.
Sand composition was investigated in two samples (222-6-4, $133-135 \mathrm{~cm}$ and $124-126 \mathrm{~cm}$ ) (Tables 7 and 10). Both sand fractions are mica dominated, particularly the upper one. Quartz, feldspar, and the heavy minerals also appear in significant amounts so that biogenous constituents show low percentages. They are plant debris, benthonic forams, and shell fragments. The smear slides show a composition of between 75 and 100 percent clastic material for this mainly silt unit: $15-25$ percent are carbonate grains. Only traces of nannofossils or other shell material occur in the silt to clay ranges. A few pellets were noted although no aragonite was recorded on the X-ray mineralogy printout. Mica and chlorite dominate the bulk mineralogy with quartz and plagioclase next in importance.

Graded Bed VI (222-9-4, $40 \mathrm{~cm}-222-9-3,80 \mathrm{~cm})$

This is a particularly thick Upper Pliocene graded unit, extending for about $110 \mathrm{~cm}$.

The grain-size distribution of the samples collected indicates obvious graded bedding. This is best illustrated by the progressive changes of the size fraction percentages, $\mathrm{C}$ parameter, median, and mean values (Table 10). The value of the standard deviation increases slightly while skewness and kurtosis increase in the lower part, but diminish for the rest of the sampled interval (Figures 10I, II, III). The C/Md diagram shows a continuous curve, with the three lower samples plotting close to one another (Figure 10IV).

Examination of the sand fractions and smear slides from specimens at Section $3,137.5 \mathrm{~cm}$ to $139.5 \mathrm{~cm}$ and Section 4, 25.5 $\mathrm{cm}$ to $27.5 \mathrm{~cm}$ shows a dominance of detrital grains (Table 2). In the smear slides, heavy minerals are an obvious constituent together with micas. Wide variation in the detrital fraction occurs, and only traces of nannofossil material were found.

The heavy mineral assemblage (Table 5) suggests a dominant metamorphic source with some contribution from an acid igneous terrain indicated by alkali feldspars and brown hornblende. (The other sample at Section $4,89 \mathrm{~cm}$ to $91 \mathrm{~cm}$ from a lower interbed is quartz-dominated, and acid igneous derivatives are more important.) The bulk X-ray mineralogy indicates higher total carbonate content in the Core 9, Section 3 sample $(13 \%)$ than in that from Core 9, Section $4(8 \%)$. This is confirmed by the carbon-carbonate data, though different values are recorded. Quartz is more important in the lower part of the bed, according to the X-ray data, but both samples are mica and chlorite dominated.

The very rate neritic (shelf-depth), benthic, and juvenile planktonic forams observed near the base of this graded bed (at 9-4, $22-24 \mathrm{~cm}$ ) represent a displaced shallow-water fauna from less than 200 meter depths (R. Fleisher, personal communication).

The remaining detailed descriptions of graded beds are from sites to the northwest of Owen Ridge for comparison with those on the Indus Cone.

Graded Bed VII (223-2-3, $40 \mathrm{~cm}-223-2-2,40 \mathrm{~cm})$

This Pleistocene bed extends over an interval of at least $100 \mathrm{~cm}$. Both the base and top have sharp contacts, and it is visually graded, which is confirmed by grain-size analysis (Table 7). Throughout the lower $58 \mathrm{~cm}$ of the bed, the sand fraction is dominant and shows only slight increase upwards.

Three samples have been collected for compositional analysis (223-2-3, 38-39 cm; 223-2-2, 139-141 cm, and 89-91 cm) (Tables 3 and 5).

The most striking feature of the sand is the general roundness of the terrigenous component though this never exceeds two-thirds of the total sand content. Pellets and shallow-water type molluscan shell debris are important sand components. These, together with the carbonate and pyrite grains, appear to be shelf derived. The higher proportion of quartz and rock fragments and the blue hornblende, tourmaline, and monazite suggest a contrast with the Indus Cone sands. Both metamorphic and igneous sources are indicated, but they are of about equal importance. The presence of hypersthene suggests an additional basic igneous influence. The monazite content is sufficiently high to disturb a geiger counter. The total carbonate content is over 50 percent and decreases upwards. Palygorskite is a significant constituent of the clay fraction, reaching 40 percent in the less than $2 \mu$ X-ray minerâlogy printout. This, together with the texture of some of the quartz grains, is indicative of some derivation of sediment from the desert hinterlands. 


\section{Graded Bed VIII (223-19-2, 40-148 cm)}

This is a graded bed, more than 1 meter thick, which occurs near the top of the Middle Miocene sequence. Table 8 outlines its grain-size characteristics. The bulk of the sand-size fraction is restricted to the basal part of the bed, and the grading is determined mainly by variations in the amount of sand and clay.

The sand composition of samples from 140-142 cm and 123-125 $\mathrm{cm}$ (Table 3) is similar to that of the Pleistocene bed previously described. Here, though, only some of the terrigenous material is rounded. The sand mineralogy again suggests both metamorphic and igneous provenance, these being of about equal importance (Table 5).

The smear slides contain only a trace of nannofossil material. Carbonate content decreases upwards from about 17 percent at the base of the bed. The X-ray mineralogical data show that quartz and plagioclase feldspar is slightly more important than mica and chlorite, and, again, palygorskite is a significant constituent of the clay mineralogy.

\section{Graded Bed IX (224-8-5, 15 to $55 \mathrm{~cm})$}

The grain-size analysis of this Middle Oligocene bed (Table 9) demonstrates that a decrease of sand and silt occurs from the base to the middle of the bed and that from here to the top of the bed this grading is repeated.

Two samples were collected for compositional studies (Tables 4 and 5), one from the middle and the other from $10 \mathrm{~cm}$ above the base. Both are generally low in biogenous material although some shelf shell debris is present. The bed shows some similarity to those from the Indus Cone in its mica/quartz dominated detrital fraction, its high percentage of metamorphic minerals and rock fragments, and its relatively low content of acid igneous derivatives. Also, the bulk X-ray mineralogy shows that mica and chlorite are by far the most abundant components with quartz and feldspar next in importance.

Nongraded Beds Nongraded Beds I and II $(222-28-5,74-97 \mathrm{~cm})$
and $(222-28-5,54-68 \mathrm{~cm})$

The 222-28-5 Upper Miocene section contains a number of thin nongraded sandy units. Bed $I$ is an unconsolidated sandy intercalation, which was sampled for both grain-size and composition data. Bed II is an overlying fully lithified calcareous sandstone horizon, which is described from its compositional aspects only.

The textural analysis of bed $\mathrm{I}$, as shown in Figure 11 and Table 10 , indicates that in the vertical dimension, the grain-size characteristics vary only slightly. A slight decrease in sand content and a corresponding increase in clay occurs at the top of the bed. The plots on the C/Md diagram are quite concentrated and the more or less linear arrangement of the plots do not follow the grading trend. The analysis shows the bed definitely to be nongraded.

The sand composition studies were carried out on a coarse fraction derived from unconsolidated material sampled at 93-94.5 $\mathrm{cm}$ in bed 1 and a thin section prepared from a sample at $63-65 \mathrm{~cm}$ in bed II (Tables 2 and 5). Although the counts of the thin section and heavy mineral mount are not directly comparable, their grain size and compositions do not differ greatly other than in the cementation aspects. In the latter, it is interesting to note the presence of both rounded and angular garnet and some basic igneous source influence with the appearance of barkevikite. Overall provenance is indicated as being mostly of metamorphic type with an acid igneous source of secondary importance. A smear slide of the unconsolidated sample shows only a trace of nannofossils in the total composition with micas dominating the detrital fraction. The bulk X-ray mineralogy of a sample between the two beds at 72-73 $\mathrm{cm}$ contains 19 percent total carbonate, mica and chlorite, 38 percent and quartz and feldspars, 37 percent. Significantly, both montmorillonite and kaolinite are present. The carbon-carbonate data indicate an upward decrease in $\mathrm{CaCO}_{3}$ through bed $\mathrm{I}$.

\section{Nongraded Bed III (221-6-3, 31 to $33 \mathrm{~cm})$}

Smear slide examination was made of the composition of this nongraded, laminated, coarse silt horizon. It has a lensoid shape, which is possibly a coring effect. Both upper and lower boundaries are sharp with the former being straight and the latter curved. The foraminifera (examined by R. Fleisher) indicate neritic or upper bathyal water depths. A nannofossil content of only 20 percent was recorded and the same percentage, for coarse micarb. The detrital component consists of quartz (17 percent), feldspar (15 percent), mica ( 6 percent), and heavy minerals ( 10 percent). The heavy minerals present are garnet, hornblende, zircon, epidote, and opaques together with rounded carbonate rhombs.

A number of nongraded beds occur at Site 224. Prominent among these are calcareous sandstones similar to that at Site 222-28-5. The thin section from the sandstone bed in Core 6, zero section, (of Early Miocene age) shows an abundance of terrigenous material, mostly of mica flakes and plant fragments. These show good preferred orientation. The heavy minerals suggest both metamorphic and acid igneous provenances. The calcareous sandstone found in the core catcher of Core 7 shows a finer grain size but again the preferred orientation of micas in a sand which is exclusively terrigenous. 